\title{
Process and Utility Systems Integration and Optimisation for Ultra-Low Energy Milk Powder Production
}

Timothy G. Walmsley*a, Martin J. Atkins ${ }^{b}$, Michael R.W. Walmsley ${ }^{b}$, Matthias Philipp ${ }^{c}$, RonHendrik Peesel ${ }^{d}$

${ }^{\text {a }}$ Sustainable Process Integration Laboratory - SPIL, NETME Centre, Faculty of Mechanical Engineering, Brno University of Technology - VUT Brno, Technická 2896/2, 61669 Brno, Czech Republic

${ }^{b}$ Energy Research Centre, School of Engineering, University of Waikato, Private Bag 3105, Hamilton, New Zealand

${ }^{\mathrm{c}}$ Technische Hochschule Ingolstadt, Institute of New Energy Systems, Esplanade 10, 85049 Ingolstadt, Germany

d Universität Kassel, Dep. Umweltgerechte Produkte und Prozesse, Kurt-Wolters-Straße 3, 34125 Kassel, Germany

walmsley@fme.vutbr.cz

\begin{abstract}
This study applies a Total Site Heat Integration approach in conjunction with a detailed process and utility model, to develop an innovative ultra-low energy milk powder plant design. The basis for the analysis is a state-of-the-art modern milk powder plant that requires $5,265 \mathrm{MJ} / \mathrm{t}_{\mathrm{p}}$ of fuel and $210.5 \mathrm{kWh} / \mathrm{t}_{\mathrm{p}}\left(58.5 \mathrm{MJ} / \mathrm{t}_{\mathrm{p}}\right)$ of electricity. The model of the modern milk powder plant was validated against industrial data and changes to process and/or utility systems are targeted and implemented into the model to understand the impacts on thermal and electrical demands and emissions. Results show that seven significant changes are beneficial: (1) pre-concentration of milk to $30 \%$ using reverse osmosis, (2) a two-stage intermediate concentrate (30\%) homogenisation to enable high solids (60\%) spray drying, (3) an ultra-low energy Mechanical Vapour Recompression
\end{abstract}


evaporator system, (4) spray dryer exhaust heat recovery, (5) condensing economiser for the boiler, (6) upgrade and integration of chiller condenser heat with hot water utility systems, and (7) recycling of air in the building ventilation system. These changes are estimated to reduce thermal energy use by $51.5 \%$, electricity use by $19.0 \%$, and emissions by $48.6 \%$ compared to a modern milk powder plant.

\section{Nomenclature}

\section{Variables}

$\Delta \quad$ Difference between two states

COP Co-efficient of Performance

Q Thermal duty (kW)

SEC Specific Energy Consumption ( $\mathrm{MJ} / \mathrm{t}_{\mathrm{p}}$ or $\mathrm{kWh} / \mathrm{t}_{\mathrm{p}}$ )

W Work or electrical energy $(\mathrm{kW})$

\section{Subscripts}

$\begin{array}{ll}* & \text { Marginal quantity } \\ \text { e } & \text { Electricity } \\ \mathrm{f} & \text { Fuel } \\ \mathrm{H} & \text { Hot } \\ \text { HP } & \text { High pressure } \\ \text { LP } & \text { Low pressure } \\ \text { p } & \text { Powder } \\ \text { rej } & \text { Rejected } \\ \text { tot } & \text { Total } \\ \text { w } & \text { Water removed }\end{array}$

\section{Introduction}

Conversion of raw milk into powdered milk is an energy intensive process requiring steam heating, chilling and electrical utilities. The milk powder process has four main processing steps: milk separation, heat treatment, evaporation, and spray drying. Over the past four 
decades, improved [1] and emerging [2] technologies have increased the energy efficiency of milk powder plants. Specific fuel consumptions have decreased from about $12,000 \mathrm{MJ}_{\mathrm{f}} / \mathrm{t}_{\mathrm{p}}$ of powder to between $5,000-6,000 \mathrm{MJ}_{\mathrm{f}} / \mathrm{t}_{\mathrm{p}}$ and specific electricity uses are in the order of 150 to $400 \mathrm{kWh} / \mathrm{t}_{\mathrm{p}}\left(111 \mathrm{MJ}_{\mathrm{e}} / \mathrm{t}_{\mathrm{p}}\right)$ [3]. The absolute fuel and electricity use and split depends on the installed technology, degree of heat integration, scale of production, and utility system efficiency.

Significant improvements in energy efficiency of the core milk powder processes through redesign and additional heat recovery have been reported in literature. For the milk separation process, Hanneman and Robertson [4] described the industry standard design for a hot milk separation plant where raw milk is separated into skim milk and cream. A key feature of the heat exchanger network design is a stream split of the raw milk for maximising heat recovery from both the hot skim milk and cream. Since this time, new plants have used new technology to perform milk separation while the milk remains cold $\left(8^{\circ} \mathrm{C}\right)$. For the heat treatment and evaporation processes, Walmsley et al. [5] demonstrated the optimal use of vapour recompression technology in an integrated process design based on the application of the appropriate placement principle for a heat pump [6]. The redesigned evaporation system achieved a dramatic $78 \%$ reduction in steam (6.40 MW) use at the expense of a $16 \%$ increase in electricity $\left(0.36 \mathrm{MW}_{\mathrm{e}}\right)$. For spray dryer systems, exhaust heat recovery is another significant opportunity to increase energy efficiency [7]. Walmsley et al. [8] developed a dryer exhaust heat recovery model, which included economic calculations and fouling predictions, and found that a $14 \%$ reduction in steam through heat recovery was most economical for a particular industrial site.

More opportunities to increase the energy efficiency of milk powder production can be achieved by shifting focus towards the complete Total Site Heat Integration (TSHI) of process and utility systems. TSHI incorporates graphical and mathematical programming methods for the integration of industrial sites [9] and locally integrated energy systems [10]. The framework also enables simultaneous selection, design and integration of unit operations through targeting [11], retrofit of process systems [12], and the integration of renewable energy [13]. The Total Site problem may also be solved using mathematical programming techniques for new design [14] and retrofit [15] problems. Improved site-wide integration through TSHI has led to increasing utility savings in slaughter and meat 
processing by $35 \%$ [16], large industrial parks in Japan about $53 \%$ [17] and Thailand by $28 \%$ [18], chemical processing clusters by $42 \%$ [19], and Kraft pulp mills about $13 \%$ [20]. TSHI has been applied to milk powder production in context of stand-alone milk powder plants [5] and multi-plant dairy factories [21] including the optimal integration of industrial solar [22]. However, these studies on milk powder plants have focused on optimising either the process or utility system, not both systems simultaneously.

Energy efficiency improvements in the milk powder process system can be realized through process change available in emerging technologies [23]. One emerging technology is high solids milk concentrate drying. At present, the milk concentrate solids entering the spray dryer are constrained to $53 \%$, above which viscosity becomes prohibitive. Emerging technologies are under development to reduce high solids milk viscosity through ultrasound techniques [24], high-solids steam injection process [25] and two-stage homogenisation of concentrate (20 - $40 \%$ ) [26], enabling the drying milk at about $60 \%$ solids in the future. Increasing the solids feed to the dryer effectively shifts evaporation load from the spray dryer to the highly integrated evaporator system, which results in significant energy reduction. Another recently commercialised technology is Reverse Osmosis (RO) membrane technology for the pre-concentration of milk up to $30 \%$ solids [27]. RO takes evaporation load away from the potentially ultra-low energy evaporator system. As a result the energy reduction opportunity is supressed. However, as a retrofit, it is an economic option to boost production, if the evaporator is the processing bottleneck.

For a milk powder plant's utility system, TSHI may be applied to target the minimum boiler flue gas temperature, thus maximising boiler efficiency, and Combined Heat and Power (CHP). A key technology for extracting the maximum heat from boiler flue gas is a condensing economiser. Although the milk powder process can have a low Pinch Temperature, e.g. $10.5^{\circ} \mathrm{C}$ [28], very few sites in New Zealand have steam boilers equipped with condensing economisers. Likewise, out of 82 New Zealand dairy processing sites, only four sites have CHP technology installed (New Zealand Heat Plant Database 2015 in Walmsley et al. [29]). Given the low uptake, it is valuable to explore options for maximising CHP as a means for improving and developing a more attractive business case. Such options include raising the initial steam pressure, the addition of new steam pressure levels to 
improve the overall heat and powder cascade [30], and the optimisation of an integrated CHP system [31].

Another area in the utility system that can contribute to energy cost reduction is waste heat recovery from chiller units. In most instances this opportunity requires an additional compressor unit to increase the pressure of the chiller's condenser, thereby upgrading its heat so that it may be substituted for boiler steam and fulfil process heat deficits. TSHI can aid the selection of the condenser pressure and identify the method for its integration, either direct with process stream and/or via the hot water utility network, using the appropriate placement principle for heat pumps [32]. The final opportunity is the milk powder plant's Heating, Ventilation and Air Conditioning (HVAC) system. At present, the system is a single pass with a steam heater to pre-heat incoming air to $28^{\circ} \mathrm{C}$ from an average of $15{ }^{\circ} \mathrm{C}$. After passing through the building air exhausts at about $33^{\circ} \mathrm{C}$. A portion of this air may be recycled to the inlet to reduce thermal energy use.

Combining the multiple process and utility system energy efficiency concepts for milk powder plants, including their coupled interactions, represents the gap in knowledge that this paper fills. The aim of this paper is develop a novel ultra-low energy process design for a milk powder plant that achieves a radical step reduction in thermal and electrical energy use and emissions. To achieve the aim, the new design takes advantage of simultaneous improvements to process and utility systems and quantifies the impacts on energy use and emissions.

In the first instance, a modern milk powder is described and then compared against a future milk powder plant design from literature [32]. Using these designs as a basis, four energy reduction opportunities in the utility system are presented followed by two opportunities in the process system. For the utility system, the investigated opportunities are: (1) increasing boiler efficiency through condensing economisers, (2) waste heat recovery from the chiller unit, (3) recycling of air in the building HVAC system, and (4) Combined Heat and Power (CHP) for electricity production. Changes to the process systems are: (1) pre-concentration of milk using RO up to $30 \%$ solids and (2) high solids spray drying up to $60 \%$ solids. The context of the study is set in New Zealand with natural gas as the primary fuel and electricity from a grid that has a high share of renewable generation. This work is a culmination and extension of work previously published by the authors [33] over the past several years. 


\section{Industrial milk powder plant designs}

\subsection{Modern milk powder plant - Design 1.0}

The milk powder process has four main processing steps: milk separation, heat treatment, evaporation, and spray drying. These processes are serviced by a common boiler for generating high pressure steam ( $\sim 0$ bar), chiller for generating chilled water, and an air compressor to generate compressed air. After being produced, milk powder is held in cool stores before transportation to market. Figure 1 presents an overview of a stand-alone milk powder factory.

At modern milk powder factories, the milk separation process separates raw milk from the farm into skim milk and cream, while the fluids are cold $\left(\sim 8^{\circ} \mathrm{C}\right)$. This process requires about $10 \mathrm{MJ} / \mathrm{t}_{\mathrm{p}}$ of hot water and $10 \mathrm{MJ} / \mathrm{t}_{\mathrm{p}}$ of chilled water. Since adopting the new technology the energy use in this section of the plant has become insignificant.

The milk heat treatment process is a combination of holding temperature $\left(80-120^{\circ} \mathrm{C}\right)$ and time $(1-60 \mathrm{~s})$, which affects the degree of protein denaturisation [34] and the flavour of the milk powder [35]. Milk enters the heat treatment process $\left(\sim{ }^{\circ} \mathrm{C}\right)$ and heats to its target heat treatment temperature. During milk heating it is important to recognise that rapid thermophile growth occurs in the temperature range of $45-60^{\circ} \mathrm{C}$ [36]. As a result strategies need to be implemented such as parallel processing lines or direct vapour contact exchangers.

The evaporation system follows the heat treatment process and the two processes are closely integrated. These two integrated systems demand $1,041 \mathrm{MJ} / \mathrm{t}_{\mathrm{p}}$ of thermal energy (excludes associated boiler losses) and $95.3 \mathrm{kWh} / \mathrm{t}_{\mathrm{p}}\left(26.5 \mathrm{MJ} / \mathrm{t}_{\mathrm{p}}\right)$ of electrical energy. The multi-train, multi-effect falling film evaporation system concentrates standardised milk from about $12 \%$ to $53 \%$ solids. In this design both Mechanical Vapour Recompression (MVR) and Thermal Vapour Recompression (TVR) are integrated with the evaporation system. Multiple effects improve the energy efficiency of the evaporator and multiple trains enable continuous operation. Each evaporator train is washed clean-in-place (CIP) about every $16 \mathrm{~h}$ to maintain food grade processing hygiene. Milk evaporators operate under vacuum with a 
pressure below $35.5 \mathrm{kPa}_{\mathrm{abs}}$ and saturation temperature of $73^{\circ} \mathrm{C}$ to avoid further denaturing of proteins and adverse effects on product flavour [36].

The final processing step is the spray dryer system, which is the largest thermal energy use with a SEC demand of $3,036 \mathrm{MJ} / \mathrm{t}_{\mathrm{p}}$. After exiting the final milk evaporator effect, milk is heated $\left(\sim 75^{\circ} \mathrm{C}\right)$ and homogenised before being atomised and sprayed co-currently with hot air $\left(210^{\circ} \mathrm{C}\right)$. Partially dry powder from the main spray dryer chambers exits through a series of fluidised beds that provides sufficient residence time to complete the drying process and cools the powder from around $80^{\circ} \mathrm{C}$ in the main chamber to about $35^{\circ} \mathrm{C}$. Spent dryer air passes through cyclones and/or baghouses to help capture any entrained particles before being exhausted to the atmosphere at about $75^{\circ} \mathrm{C}$.

\subsection{Future milk powder plant - Design 2.0}

The future milk powder plant design adopts a ultra-low energy evaporation system [5] (Figure 2) and dryer exhaust heat recovery [8] (Figure 3) to dramatically decrease overall energy use. Other processes remain the same as a modern milk powder plant. Overall these improvements can potentially decrease thermal energy use by $1,571 \mathrm{MJ} / \mathrm{t}_{\mathrm{p}}(29.8 \%)$ in tradeoff with an increase in electricity use by $9.7 \mathrm{kWh} / \mathrm{t}_{\mathrm{p}}\left(2.7 \mathrm{MJ} / \mathrm{t}_{\mathrm{p}}, 4.6 \%\right)$. There is also a $26.8 \%$ reduction in carbon emissions.

The redesigned low energy evaporator system is presented in Figure 2. The redesigned evaporator has three important changes compared to a modern evaporator system [5]. These are: (1) both evaporator effects are integrated with MVR resulting in less low grade waste heat, (2) the heat treatment section is integrated with MVR to reduce direct steam injection, and (3) an improved heat exchanger network design that enables maximum extraction of condensate heat, which exits the system at $13^{\circ} \mathrm{C}$ (instead of $30^{\circ} \mathrm{C}$ ).

Dryer exhaust heat recovery uses a liquid coupled loop to indirectly integrate with the dryer inlet air (Figure 3). A coupled loop system is applied due to the requirement to separate the exhaust air outflow and feed air inflow. The final temperature of the exhaust air should be kept above $55^{\circ} \mathrm{C}$ to avoid accelerated powder fouling [37]. 
In Section 6, a full comparison between the modern milk powder plant (Design 1.0) and potential future low-energy plant designs (Design 2.0 - 3.0) is presented using thermal and electrical SEC metrics (see Table 3) and specific emissions per tonne of powder produced (see Table 4).

\section{Methods}

A scenario based process and utility systems modelling approach is taken in this paper to determine the extent that energy use and emissions may be reduced for milk powder production. As a result, a comprehensive mass and energy process and utility model of a milk powder factory has been implemented in an Excel $^{\mathrm{TM}}$ spreadsheet and validated against industrial data from New Zealand's current milk powder plant design as well as an anticipated future plant design. The model consists of sub-models that contain process flow and design details for each processing step and utility unit operation. This includes the design of the heat exchanger network for each process, where applicable. The base process models for the milk separation, evaporation and spray drying processing steps were previously developed and reported by Walmsley et al. [5]. This paper reports the extension of the base model, to investigate additional concepts for minimising energy use and emissions across the entire site.

Sub-models within process and utility model are linked through both mass and heat transfer. For example, concentrate exiting the evaporation system is an input to the spray dryer model. Steam generated in the boiler and chilled water from the chilled are driven by the process demands. In general, Figure 1 presents the major linkages between the various process and utility operations.

Six energy efficiency opportunities within various process and utility operations have been investigated using the milk powder plant process and utility model.

Investigated opportunities in the utility system include:

(1) increasing boiler efficiency through condensing economisers,

(2) waste heat recovery from the chiller unit,

(3) recycling of air in the building HVAC system, and 
(4) Combined Heat and Power (CHP) for electricity production.

Investigated process changes include:

(1) pre-concentration of milk using RO up to $30 \%$ solids, and

(2) high solids spray drying up to $60 \%$ solids.

To investigate these opportunities, new detailed models were needed for: reverse osmosis milk pre-concentration model, two-stage homogenisation model, steam boiler with back pressure steam turbine model, and an ammonia chiller model. These models are described in sections $3.1-3.5$. Several process and utility designs result from the investigation. Table 1 summaries the process and utility design changes that are incorporated into Design $2.0-3.0$. TSHI [38] has been applied to target the integration potential for additional energy reduction in the milk powder utility system. Total Site Profiles and Site Utility Grand Composite curve play important roles in targeting additional heat recovery in the utility system. For example, the boiler flue gas is pinched against the Site Utility Grand Composite to target heat recovery and its final temperature. It is important to note that as changes are made to a process, its stream data changes, which then affects its energy generation efficiency or process heat demands. Once the energy efficiency opportunity is targeted, practical design modifications are developed through the application of conventional Pinch heuristics and good engineering judgement. Appendix A provides the stream data for the basis of the Total Site Profiles related to the three generations of design (Designs $1.0-3.0$ ).

In determination of changes to emissions, emissions factors for New Zealand are applied in the analysis to determine the effect on emissions from the various energy efficiency concepts. New Zealand had a grid emissions factor of $0.0359 \mathrm{~kg}_{\mathrm{cO} 2 \mathrm{e}} / \mathrm{MJ}$ in 2015 as a result of a high proportion of renewable generation [39]. Process heat from natural gas has an emissions factor of $0.0533 \mathrm{~kg}_{\mathrm{CO} 2-\mathrm{e}} / \mathrm{MJ}[40]$.

\subsection{Principal milk powder process models}

The milk separation process in modern milk powder plants operates at the milk storage temperature of about $8^{\circ} \mathrm{C}$. As a result, the process model for this section of the factory 
splits the raw milk into skim milk (92\%) and cream (8\%). Separation percentages are based on industrial process flow data.

A detailed heat and mass balance process model of a multi-effect falling film milk evaporator system, including the possibility of both MVR and/or TVR, has been developed. The process design in the model is flexible in that the user can choose the number of evaporation effects $(1-3)$, operating pressures and temperature, heat exchanger network design, as well as the application of MVR and/or TVR technologies. The model applies standard water/steam properties (IAPWS IF-97) and milk properties [41]. Based on industrial data, low pressure mechanical compressors (MVR) have a calculated isentropic efficiency of $80 \%$. TVR (or thermocompressor) performance is determined using the model of Sargolzaei et al. [42], assuming choked flow through the thermocompressor. The process design for the current set-up of evaporation system, which is described in section 2.1 (see Walmsley et al. [5]) has been validated using industrial plant data.

The spray dryer model followed a similar development procedure as the other two process models. A spreadsheet describing its mass and energy flows was constructed and compared with industrial process data for the current dryer set-up, as shown in Figure 3. Spray dryer exhaust heat recovery is added to improve its energy efficiency, as reported in Walmsley et al. [8]. High solids drying assumes similar dryer chamber and exhaust air outlet temperatures may be achievable and no other process challenges constrain its performance.

\subsection{Reverse osmosis model for milk pre-concentration}

Milk is commercially concentrated using a RO process up to $30 \%$ solids for whole milk and $34 \%$ solids for skim milk [27]. The recommended operating pressure for industrial RO systems is between 3.1-4.1 MPa [43]. Industrial data on the energy performance of RO filtration for milk is difficult to obtain but has been reported in literature to consume 3.9 $10.0 \mathrm{kWh} / \mathrm{t}_{\mathrm{w}}\left(1.1-2.8 \mathrm{MJ}_{\mathrm{e}} / \mathrm{t}_{\mathrm{p}}\right)$ of water removed [2]. As a result, three cases - high, mid and low energy use - for concentrating milk to $30 \%$ are investigated as shown in Table 2 . 


\subsection{Two-stage homogenisation model for high solids spray drying}

Milk concentrate viscosity reduction, which enables high solids spray drying, is achieved using a two-stage homogenisation when the milk reaches a concentration between 20 and $40 \%$ solids [26]. The homogenisation process was considered a better option than ultrasound treatment [24] because of its greater potential for viscosity reduction and highsolids steam injection process [25] because of its lower energy demand.

The two stage homogenisation process uses pressures of $14.0 \mathrm{MPa}$ for stage one and 4.0 MPa for stage two as recommended by Bodenstab [26]. Figure 4 estimates the electricity requirement for homogenising at a range of solids with an assumed pump efficiency of $75 \%$. For milk with the recommended concentration of $30 \%$ solids, the electrical use is $8.9 \mathrm{kWh} / \mathrm{t}_{\mathrm{p}}\left(2.5 \mathrm{MJ} / \mathrm{t}_{\mathrm{p}}\right)$ for stage one and $2.5 \mathrm{kWh} / \mathrm{t}_{\mathrm{p}}\left(0.7 \mathrm{MJ} / \mathrm{t}_{\mathrm{p}}\right)$ for stage 2 . Bodenstab [26] claims this additional processing step can facilitate spray drying using up to a $60 \%$ solids concentrate.

\subsection{Steam boiler and back pressure steam turbine model}

The natural gas steam boiler model, including a deaerator, blowdown vessel and feed water pump, was modelled using Excel Add-in JSteam ${ }^{T M}$ (www.inverseproblem.co.nz). TSHI techniques are applied to maximise boiler efficiency. The composite curve of boiler flue gas (initially at $140^{\circ} \mathrm{C}$ ), after generating steam and preheating combustion air using a standard economiser, is shifted and pinched against the Total Site Source Profile to target the minimum flue gas temperature, which leads to maximising boiler efficiency.

For CHP, the back pressure steam turbine model estimated performance using the M-P turbine model [44], which is the best available empirical correlation for single and multiple extraction turbines. Where a turbine (or steam drive) rating falls below the M-P turbine model's lower limit, the model estimates work assuming an isentropic efficiency of $65 \%$.

\subsection{Ammonia chiller model}

The chiller model uses the vapour compression cycle with ammonia as the working fluid, a compressor efficiency of $53 \%$, a condenser pressure of $2.0 \mathrm{MPa}$, and a Co-efficient of 
Performance (COP) of 2.3. Thermophysical properties are called from NIST'S REFPROP ${ }^{T M}$. The standard chiller may also generate useful heat (i.e. heat pump) by raising the condenser pressure to $2.6 \mathrm{MPa}$, which has a saturation temperature of $60{ }^{\circ} \mathrm{C}$. The COP of this unit is 1.8 for chilling and 2.8 for heating. Since the process requires a chiller, it's useful to understand the performance of expending additional electricity to upgrade the condenser heat. The marginal COP* for heating in the combined system may be defined by:

$\mathrm{COP}_{\mathrm{H}}^{*}=\frac{\mathrm{Q}_{\mathrm{H}(\mathrm{HP})}-\mathrm{Q}_{\mathrm{rej}}}{\mathrm{W}_{\mathrm{HP}}-\mathrm{W}_{\mathrm{LP}}}$

Where subscripts HP refers to a high pressure condenser, LP refers to a low pressure condenser, and rej refers to rejected heat. If all the condenser heat is able to heat process streams (i.e. the rejected heat is zero), then the marginal COP of heating is 13.4 .

\section{Energy efficiency opportunities in the utility system}

This section explores four energy efficiency opportunities in the utility system. The basis for the analysis is the future milk powder plant design (Design 2.0). TSHI is applied to target heat integration while the Milk Powder Plant model helped estimate the actual energy change.

\subsection{Maximising boiler energy efficiency through condensing economisers}

Standard industrial steam boilers for milk powder production operate at 40 bar $\left(250^{\circ} \mathrm{C}\right.$ saturated) and are fitted with an economiser. The economiser preheats pressurised boiler feed water before it enters the main evaporation tubes. Depending on the boiler design the flue gas enters the economiser at up to $350^{\circ} \mathrm{C}$ and leaves above the acid dew point at $140{ }^{\circ} \mathrm{C}$. An additional condensing economiser can be installed to capture more flue gas heat. There is also a water dew point, which for a natural gas boiler (as considered in this study) is about $60^{\circ} \mathrm{C}$ while a coal fired boiler is $40^{\circ} \mathrm{C}$. Extracting additional heat, both sensible and latent (if useful), maximises boiler efficiency and minimises fuel use. 
Two sinks within the boiler plant to match with the flue gas in a condensing economiser are the combined condensate return / make-up water flow and the combustion air inlet. The condensate returns from servicing the process at $85{ }^{\circ} \mathrm{C}$, and once combined with the makeup water, the temperature decreases to $68{ }^{\circ} \mathrm{C}$ for the current process design and $82{ }^{\circ} \mathrm{C}$ for the future design. This difference in temperature is due to current plant design having a lower condensate return percent compared to the expected percent in the future design (74 \% to $94 \%$ ). The future process design uses less direct steam injection and therefore has a higher condensate return percentage. Matching the combined water flow with the flue gas has a maximum duty of $69 \mathrm{MJ} / \mathrm{t}_{\mathrm{p}}$. Preheating the combustion is another option, but is undesirable due to poor heat transfer coefficients of gas to gas heat exchange. Further sink options beyond the boiler system may be found using TSHI techniques.

The source profile of the Total Site Profiles together with targeted steam and hot water utility profiles may be pinched with the shifted boiler flue gas flow using a $\Delta \mathrm{T}_{\text {cont }}$ of $12.5^{\circ} \mathrm{C}$. Figure 5 plots these source, sink and utility profiles for the future process design. The targeted final flue gas temperature is $58.4{ }^{\circ} \mathrm{C}$ and the additional heat extraction from the flue gas is $180 \mathrm{MJ} / \mathrm{t}_{\mathrm{p}}$. The target is influenced by the hot water utility temperature selection. The additional heat extraction from the flue gas has the knock on effect of reducing boiler fuel consumption to meet the process heat demand, which in turns means the flue gas flow rate slightly decreases. As a result the process and utility model becomes an important tool to capture these coupled effects.

The hot water utility system, as shown in Figure 5 , is one sink option for the condensing economiser. This option would require additional piping from the boiler house to the processing buildings. At present the boiler supplies the process with only two steam pressure levels (using a let-down valve) and returns hot condensate in a separate line. Another sink option that requires minimal additional piping between the boiler and process locations is to return cold condensate $\left(35^{\circ} \mathrm{C}\right)$ by placing the heat in a process sink. For the future process design, the Fluidised Bed air flows may be matched with the hot condensate flows to achieve a duty of $232 \mathrm{MJ} / \mathrm{t}_{\mathrm{p}}$. The cold condensate, combined with a small amount of make-up water, then extracts an additional $197 \mathrm{MJ} / \mathrm{t}_{\mathrm{p}}$ in a condensing economiser. The overall result is a specific fuel reduction of $227 \mathrm{MJ} / \mathrm{t}_{\mathrm{p}}$, which is actually greater than the initial integration target. 


\subsection{Chiller waste heat upgrade and recovery}

The chiller system is an essential utility supply operation of chilled water for process cooling. The condenser is normally air-cooled in a closed loop. With ammonia as the working fluid, the condenser operates at $2.0 \mathrm{MPa}$, which is a saturation temperature of $49^{\circ} \mathrm{C}$. By increasing the compression to $2.6 \mathrm{MPa}$, the saturation temperature increases to $60{ }^{\circ} \mathrm{C}$ and the heat may be integrated into the LTHW, which has a supply temperature of $55^{\circ} \mathrm{C}$. This can be achieved by installing a second compression stage.

Figure 6 presents how a combine chiller/heat pump system appropriately integrates with the Site Source and Sink Profiles. The Site Sink Profile excludes the portion of heat demand for the Fluidised Bed air streams that is satisfied indirectly through the condensate system using the boiler flue gas. The target boiler heat displacement is $85 \mathrm{MJ} / \mathrm{t}_{\mathrm{p}}$ and its integration results in a specific fuel reduction of $101 \mathrm{MJ} / \mathrm{t}_{\mathrm{p}}$. Electrical use increases by $1.8 \mathrm{kWh} / \mathrm{t}_{\mathrm{p}}$ $\left(0.5 \mathrm{MJ}_{\mathrm{e}} / \mathrm{t}_{\mathrm{p}}\right)$, which is a marginal $\mathrm{COP}_{\mathrm{H}}$ of 13 . In the future plant design, the LTHW system is used to heat air flows and direct use water applications such as process cleaning, tanker washing, and lactose powder reconstitution.

At some existing dairy factories there is a substantial amount of waste heat, not just from the chiller unit, rejected at about $40^{\circ} \mathrm{C}$. Future work will look at both the integration of heat pumps using chiller and other waste heat, as well as the internal design of the heat pump cycle to match process demand profiles while maximising its COP.

\subsection{HVAC air recycle for energy reduction}

The thermal energy demand to keep the building that houses the milk powder plant is on average $83 \mathrm{MJ} / \mathrm{t}_{\mathrm{p}}$. The system operates intermittently depending on the temperature of the incoming fresh air using a temperature control loop. At present, the system is a single pass and a steam heater increases the incoming air temperature from an average of $15^{\circ} \mathrm{C}$ to $28{ }^{\circ} \mathrm{C}$. After passing through the building air exhausts at about $33^{\circ} \mathrm{C}$ through roof ducts. In this opportunity a portion of the exhaust air may be recycled to the inlet as a means of energy recovery. With an exhaust air to fresh air recycle ratio of $2: 1$, the thermal load decreases to $8 \mathrm{MJ} / \mathrm{t}_{\mathrm{p}}$. 


\subsection{Combined heat and power}

The final investigated opportunity within the utility system is CHP using a back pressure steam turbine for electricity production. Using the existing two steam levels and a turbine to drop the required steam from 40 bar to 10 bar for the MPS demand gives an electricity production of $46.4 \mathrm{kWh} / \mathrm{t}_{\mathrm{p}}\left(12.9 \mathrm{MJ} / \mathrm{t}_{\mathrm{p}}\right)$, which for a production rate of $30 \mathrm{t}_{\mathrm{p}} / \mathrm{h}$ is a $1.4 \mathrm{MW}$ turbine, at an isentropic efficiency of $67 \%$. A turbine installation for only $1.4 \mathrm{MW}$ of electricity generation struggles to find economic justification. Alternatively, plant equipment such as fans may be driven by steam turbines instead of electric motors.

CHP can be increased by adding a VHPS level with superheat and an LPS level. The LPS level requires additional piping to go from the boiler house to the process building. Figure 7 presents the enhanced CHP system using the Total Site Profiles. These changes to the steam system increases electricity production by $133 \%$ to $108.1 \mathrm{kWh} / \mathrm{t}_{\mathrm{p}}\left(30.0 \mathrm{MJ} \mathrm{e}_{\mathrm{e}} / \mathrm{t}_{\mathrm{p}}\right)$. In this case self-generation of electricity reduce grid draw by $49 \%$.

Within the New Zealand context, the adoption of CHP can lead to an increase in emissions. New Zealand's average grid emissions factor of $0.0359 \mathrm{~kg}_{\mathrm{cO} 2 \mathrm{e}} / \mathrm{MJ}$ is significantly lower than an equivalent fuel-to-electricity emissions factor of $0.0592 \mathrm{~kg}_{\mathrm{cO} 2-\mathrm{e}} / \mathrm{MJ}$. The fuel-to-electricity emissions factor is estimated using a $90 \%$ efficient fuel-to-thermal generation, which represents the efficiency of a boiler with a condensing economiser. Since the grid emissions is $39 \%$ lower, CHP for industrial sites in New Zealand has a negative emissions and environmental impact.

\section{Energy efficiency opportunities in the process system}

This section explores two process system change opportunities for energy reduction. The basis for the analysis is the future milk powder process design (2.0). The Milk Powder Plant model is applied to determine changes in energy use. Tables 2 and 3 provide the breakdowns of energy use and emissions for each of the process changes. Table 1 identifies the changes compared to a modern milk powder, Design 1.0, for each design. For each process change it is assumed the total amount of hot water for cleaning is constant. 


\subsection{Pre-concentration of milk using reverse osmosis - Design 2.1}

Implementing a RO milk pre-concentration stage for pre-concentrating milk, assuming the mid SEC of $7.0 \mathrm{kWh} / \mathrm{t}_{\mathrm{w}}\left(1.9 \mathrm{MJ} / \mathrm{t}_{\mathrm{w}}\right)$, before the MVR evaporators, changes the overall heat and electrical balance (Table 3). Figure 8 shows impact of varying the concentrate solids output from RO on the thermal and electrical energy demands.

For an output of $30 \%$ solids, electricity use in Design 2.1 decreases by $21.8 \%$ compared to Design 2.0. The electricity use reduction is due to the estimated SEC of the RO process (7.0 kWh/t $t_{w}$ or $1.9 \mathrm{MJ} / \mathrm{t}_{\mathrm{p}}$ ) being lower than MVR evaporators $\left(12.0 \mathrm{kWh} / \mathrm{t}_{\mathrm{w}}\right.$ or $\left.3.3 \mathrm{MJ} / \mathrm{t}_{\mathrm{p}}\right)$. With the new thermal balance of the MVR evaporator, excess vapour is no longer available for upgrading to integrate with the milk heat treatment process (Figure 2). This change has the effect of decreasing MVR electricity consumption by $10.0 \mathrm{kWh} / \mathrm{t}_{\mathrm{p}}\left(2.8 \mathrm{MJ} / \mathrm{t}_{\mathrm{p}}\right)$ and increasing thermal demand in the heat treatment process by $141 \mathrm{MJ} / \mathrm{t}_{\mathrm{p}}$. There is a second increase to thermal demand of $49 \mathrm{MJ} / \mathrm{t}_{\mathrm{p}}$ for cleaning. These thermal demand increases are caused by a substantially lower quantity of available hot condensate and excess vapour from the lower duty evaporator process. The overall net effect is an increase in thermal load by $6.5 \%$ compared to Design 2.0. For a high SEC for RO $\left(10.0 \mathrm{kWh} / \mathrm{t}_{\mathrm{w}}\right.$ or $\left.2.8 \mathrm{MJ} / \mathrm{t}_{\mathrm{w}}\right)$, there is still a $14.8 \%$ reduction in electricity use while for a low SEC for RO $\left(3.9 \mathrm{kWh} / \mathrm{t}_{\mathrm{w}}\right.$ or $\left.1.1 \mathrm{MJ} / \mathrm{t}_{\mathrm{w}}\right)$ the reduction is $28.8 \%$.

With implementing the RO process, there is a trade-off between thermal and electrical demands. Using the net changes, an equivalent thermal-to-electrical $\mathrm{COP}_{\mathrm{t} \text {-e }}$ may be defined

$\mathrm{COP}_{\mathrm{t}-\mathrm{e}}=\frac{-\Delta \mathrm{W}_{\text {net }}}{\Delta \mathrm{Q}_{\mathrm{net}}}$

The $\mathrm{COP}_{\mathrm{t}-\mathrm{e}}$ may be determined for a range of output concentrations from RO and for low and high SEC estimates as shown in Figure 9. As an isolated process change, a $\mathrm{COP}_{\mathrm{t} \text {-e }}$ of 0.68 is excellent if compared with a typical heat engine. However for New Zealand, there is resistance to this isolated process change from a carbon emissions viewpoint. The minimum required $\mathrm{COP}_{\mathrm{t}-\mathrm{e}}$ to effect a decrease in emissions is 1.5. As a result, overall carbon emissions rises by $6.6 \mathrm{~kg}_{\mathrm{CO} 2-\mathrm{e}} / \mathrm{t}_{\mathrm{p}}$ (Table 4$)$. 


\subsection{High solids feed to milk spray dryer - Design 2.2}

High solids feed (60\%) spray drying of milk greatly reduces thermal load by $22.7 \%$ while electricity use increases by $2.1 \%$ compared to Design 2.0. Total emissions for satisfying both thermal and electrical energy demands decreases by $19.5 \%$. Thermal energy demand decreases chiefly due to the shifting of evaporation load from the spray dryer process to the MVR evaporator process. The increased electricity use is the result of a combination of changes. In the heat treatment and evaporator process, electricity use increases by $16.1 \mathrm{kWh} / \mathrm{t}_{\mathrm{p}}\left(4.5 \mathrm{MJ} / \mathrm{t}_{\mathrm{p}}\right)$, of which the additional two-stage homogenisation process step contributes $71 \%$. The remaining increase results from the high MVR electrical draw for outputting a higher solids product $(60 \%)$. The electrical-to-thermal COP for this process change is

$\mathrm{COP}_{\mathrm{e}-\mathrm{t}}=\frac{-\Delta \mathrm{Q}_{\text {net }}}{\Delta \mathrm{W}_{\text {net }}}=\frac{837 \mathrm{MJ} / \mathrm{t}_{\mathrm{p}}}{4.5 \mathrm{kWh} / \mathrm{t}_{\mathrm{p}}}=51.5$

This effective COP is high, indicating the proposed change contains substantial benefit. High solids drying of milk is therefore recommended as an area of future research. Further technology development and optimisation may prove whether the patented two-stage homogenisation concept [26] is effective for an industrial process.

\subsection{Combined process changes - Design 2.3}

The third process change concept is a combination of RO milk pre-concentration (based on the mid SEC) and high solids feed (60\%) spray drying. This combination of changes, represented as Design 2.3, provides reductions of $21.5 \%$ in thermal energy use, $19.6 \%$ in electricity use, and $21.3 \%$ in emissions compared to Design 2.0. For this design scenario, the positioning of the additional two-stage homogenisation process step for high solids drying is performed using $30 \%$ concentrate from the RO process, which is within the recommended operational window [26].

There is a degree of synergy in implementing both process changes. The thermal energy use increase in Design 2.1 is $241 \mathrm{MJ} / \mathrm{t}_{\mathrm{p}}$ compared to Design 2.0. However, after implementing 
high solids drying (Design 2.2), thermal energy use for Design 2.3 increases by only $44 \mathrm{MJ} / \mathrm{t}_{\mathrm{p}}$. This synergy is derived from the increased evaporation load on the evaporator system in Design 2.3 compared to Design 2.1. As a result there is additional heat to cascade to preheat milk and generate hot water for cleaning.

These process change concepts also raise the possibility of retrofitting existing milk powder plants to increase both through-put and energy efficiency. Installing a pre-concentration RO system prior to the evaporator system means the evaporator system can handle approximately a three-fold increase in through-put for the same evaporation load. Likewise, reaching a higher solids at the exit of the evaporator decreases the evaporation load on the spray dryer by $25.8 \%$, which means that for the same evaporation load, through-put for the dryer can increase by $34.8 \%$. For this retrofit scenario, the dryer becomes the clear process bottleneck to further increases in production.

\section{Ultra-low energy milk powder plant - Design 3.0}

An ultra-low energy milk powder plant design (Design 3.0) is developed based on simultaneously implementing the following processes and actions: (1) pre-concentration of milk to $30 \%$ using RO, (2) high solids (60\%) spray drying as a result of a two-stage mild concentrate homogenisation, (3) installation of a condensing economiser for the boiler, indirectly integrated with the fluidised bed air flows through the steam condensate system, (4) upgrade and integration of chiller condenser heat with the hot water utility system, and (5) recycling of air in the building HVAC system. These improvements are added to energy reductions obtained by: (1) an ultra-low energy milk heat treatment and evaporator system and (2) dryer exhaust heat recovery (Table 1). CHP has not been incorporated into Design 3.0 because for the case study, emissions (a key driving factor) is likely to increase.

The output concentration from the RO process is optimised to ensure reductions in energy and emissions. It was noted in Design 2.1 - RO pre-concentration as an isolated process change - increased overall emissions. A similar investigation for a range of RO concentration outputs has been conducted for Design 3.0 as shown in Figure 10. For this new design, the minimum thermal and electrical energy requirements occur when the output concentration reaches the imposed limit of $30 \%$ solids. Beyond $30 \%$ solids, there is 
a degree of diminishing returns with respect to energy reduction. Future work should incorporate an improved model for the RO process, given reliable data becomes available, where the SEC is a function of concentration.

The combination of proposed process changes influences the optimal design of the heat treatment and evaporator systems. This is chiefly due to the lower quantity of hot condensate for heat integration. Figure 11 presents the process flow diagram and grid diagram of the new integrated design for the heat treatment and evaporator process, which is implemented as part of the ultra-low energy milk powder plant. Two changes from the previous design of Walmsley et al. [5] (Figure 2) are: (1) elimination of an integrated MVR unit within the heat treatment process and (2) a shift in load from the condensate heat recovery exchanger to the vapour bleed exchanger. These changes have the benefit of simplifying the overall system design. It is important to note that the preheat exchanger using vapour from the first effect needs two parallel processing lines for mid-run cleaning to control thermophile growth in the critical temperature range of $45-60{ }^{\circ} \mathrm{C}$.

The process design is compared to a modern milk powder plant (Design 1.0) in Figure 12 using Sankey diagrams that show where thermal and electrical energy demand occurs within the process, where water is removed, and how much cream and powder are produced. The ultra-low energy design achieves reductions of $51.5 \%$ in thermal energy, $19.0 \%$ in electricity use, and $48.6 \%$ in emissions compared to the modern milk powder plant. This new design with a step reduction in energy achieves substantially greater energy efficiency than studies in literature, i.e. the optimised evaporation process design of Walmsley et al. [5], the optimised Total Site utility systems design of Walmsley et al. [33], and the best design using emerging technologies by Moejes and van Boxtel [2].

Future experimental research is required to de-risk the proposed milk powder plant design, particularly for high solids drying, thus enabling full realisation of the energy and emissions savings. A detailed capital cost assessment of the proposed energy efficiency improvements can also be undertaken in future work to determine overall economic justification. 


\section{Conclusions}

Process changes and utility systems optimisation, together with improved Total Site integration, has potential to reduce a modern milk powder plant's thermal energy use by $51.5 \%$, electricity use by $19.0 \%$, and emissions by $48.6 \%$. To achieve this level of energy and emissions savings, the following seven implementations are required: (1) preconcentration of milk to $30 \%$ using reverse osmosis technology, (2) a two-stage $30 \%$ concentrate homogenisation for viscosity reduction to enable high solids (60 \%) spray drying, (3) an ultra-low energy MVR evaporation system, (4) dryer exhaust heat recovery, (5) installation of a condensing economiser for the boiler, (6) upgrade and integration of chiller condenser heat for use with the hot water utility system, and (7) recycling of air in the building HVAC system. Within the New Zealand context, Combined Heat and Power is not recommended due to an increase in emissions. Future work can focus on de-risking the proposed improvements, especially high solids spray drying, as well as performing a detailed cost-benefit analysis.

\section{Acknowledgements}

This research has been supported by the EU project "Sustainable Process Integration Laboratory - SPIL", project No. CZ.02.1.01/0.0/0.0/15_003/0000456 funded by EU "CZ Operational Programme Research and Development, Education", Priority 1: Strengthening capacity for quality research.

\section{References}

[1] T. Xu, J. Flapper, Reduce energy use and greenhouse gas emissions from global dairy processing facilities, Energy Policy. $39 \quad$ (2011) 234-247. doi:10.1016/j.enpol.2010.09.037.

[2] S.N. Moejes, A.J.B. van Boxtel, Energy saving potential of emerging technologies in milk powder production, Trends in Food Science \& Technology. (2017). doi:10.1016/j.tifs.2016.10.023.

[3] C.A. Ramírez, M. Patel, K. Blok, From fluid milk to milk powder: Energy use and energy efficiency in the European dairy industry, Energy. 31 (2006) 1984-2004. doi:10.1016/j.energy.2005.10.014. 
[4] H. Hanneman, L.J. Robertson, Heat recovery systems, in: Energy Use in Dairy Processing, International Dairy Federation, Brussels, Belgium, 2005.

[5] T.G. Walmsley, M.J. Atkins, M.R.W. Walmsley, J.R. Neale, Appropriate placement of vapour recompression in ultra-low energy industrial milk evaporation systems using Pinch Analysis, Energy. 116, Part 2 (2016) 1269-1281. doi:10.1016/j.energy.2016.04.026.

[6] D.W. Townsend, B. Linnhoff, Heat and power networks in process design. Part I: Criteria for placement of heat engines and heat pumps in process networks, AIChE J. 29 (1983) 742-748. doi:10.1002/aic.690290508.

[7] M.K. Krokida, G.I. Bisharat, Heat Recovery from Dryer Exhaust Air, Drying Technology: An International Journal. 22 (2004) 1661.

[8] T.G. Walmsley, M.R.W. Walmsley, M.J. Atkins, J.R. Neale, A.H. Tarighaleslami, Thermoeconomic optimisation of industrial milk spray dryer exhaust to inlet air heat recovery, Energy. 90, Part 1 (2015) 95-104. doi:10.1016/j.energy.2015.03.102.

[9] P.Y. Liew, S.R. Wan Alwi, P.S. Varbanov, Z.A. Manan, J.J. Klemeš, Centralised utility system planning for a Total Site Heat Integration network, Computers \& Chemical Engineering. 57 (2013) 104-111. doi:10.1016/j.compchemeng.2013.02.007.

[10] S. Perry, J. Klemeš, I. Bulatov, Integrating waste and renewable energy to reduce the carbon footprint of locally integrated energy sectors, Energy. 33 (2008) 1489-1497. doi:10.1016/j.energy.2008.03.008.

[11] T.G. Walmsley, A Total Site Heat Integration design method for integrated evaporation systems including vapour recompression, Journal of Cleaner Production. 136, Part B (2016) 111-118. doi:10.1016/j.jclepro.2016.06.044.

[12] P.Y. Liew, J.S. Lim, S.R. Wan Alwi, Z. Abdul Manan, P.S. Varbanov, J.J. Klemeš, A retrofit framework for Total Site heat recovery systems, Applied Energy. 135 (2014) 778-790. doi:10.1016/j.apenergy.2014.03.090.

[13] P. S. Varbanov, J.J. Klemeš, Integration and management of renewables into Total Sites with variable supply and demand, Computers \& Chemical Engineering. 35 (2011) 18151826. doi:10.1016/j.compchemeng.2011.02.009.

[14] A. Nemet, J.J. Klemeš, Z. Kravanja, Mathematical Programming Approach to Total Site Heat Integration, Computer Aided Chemical Engineering. 33 (2014) 1795-1800. doi:10.1016/B978-0-444-63455-9.50134-3.

[15] L. Čuček, Z. Kravanja, Retrofit of Total Site Heat Exchanger Networks by Mathematical Programming Approach, in: M. Martín (Ed.), Alternative Energy Sources and Technologies, Springer International Publishing, 2016: pp. 297-340. doi:10.1007/9783-319-28752-2_11.

[16] A. Fritzson, T. Berntsson, Energy efficiency in the slaughter and meat processing industry-opportunities for improvements in future energy markets, Journal of Food Engineering. 77 (2006) 792-802. doi:10.1016/j.jfoodeng.2005.08.005.

[17] K. Matsuda, Y. Hirochi, H. Tatsumi, T. Shire, Applying heat integration total site based pinch technology to a large industrial area in Japan to further improve performance of highly efficient process plants, Energy. 34 (2009) 1687-1692. doi:10.1016/j.energy.2009.05.017.

[18] K. Matsuda, Y. Hirochi, D. Kurosaki, Y. Kado, Application of Area-wide Pinch Technology to a Large Industrial Area in Thailand, Chemical Engineering Transactions. 39 (2014) 1027-1032. doi:10.3303/CET1439172. 
[19] R. Hackl, S. Harvey, From heat integration targets toward implementation - A TSA (total site analysis)-based design approach for heat recovery systems in industrial clusters, Energy. 90, Part 1 (2015) 163-172. doi:10.1016/j.energy.2015.05.135.

[20] J.C. Bonhivers, E. Svensson, T. Berntsson, P.R. Stuart, Comparison between pinch analysis and bridge analysis to retrofit the heat exchanger network of a kraft pulp mill, Applied Thermal Engineering. $70 \quad$ (2014) 369-379. doi:10.1016/j.applthermaleng.2014.04.052.

[21] T.G. Walmsley, M.R.W. Walmsley, M.J. Atkins, J.R. Neale, Integration of industrial solar and gaseous waste heat into heat recovery loops using constant and variable temperature storage, Energy. 75 (2014) 53-67. doi:10.1016/j.energy.2014.01.103.

[22] T.G. Walmsley, M.R.W. Walmsley, A.H. Tarighaleslami, M.J. Atkins, J.R. Neale, Integration options for solar thermal with low temperature industrial heat recovery loops, Energy. 90, Part 1 (2015) 113-121. doi:10.1016/j.energy.2015.05.080.

[23] I.C. Kemp, Pinch analysis and process integration: a user guide on process integration for the efficient use of energy, Butterworth-Heinemann, Oxford, UK, 2007.

[24] B. Zisu, M. Schleyer, J. Chandrapala, Application of ultrasound to reduce viscosity and control the rate of age thickening of concentrated skim milk, International Dairy Journal. 31 (2013) 41-43. doi:10.1016/j.idairyj.2012.04.007.

[25] E.G. Murphy, J.T. Tobin, Y.H. Roos, M.A. Fenelon, A high-solids steam injection process for the manufacture of powdered infant milk formula, Dairy Sci. \& Technol. 93 (2013) 463-475. doi:10.1007/s13594-013-0116-7.

[26] S. Bodenstab, Process for the preparation of milk powder, EP1259117 B1, 2005.

[27] Tetra Pak, Membrane Filtration Reverse Osmosis, (2016). www.tetrapak.com:80/processing/membrane-filtration/reverse-osmosis (accessed November 30, 2016).

[28] T.G. Walmsley, M.R.W. Walmsley, M.J. Atkins, J.R. Neale, Improving energy recovery in milk powder production through soft data optimisation, Applied Thermal Engineering. 61 (2013) 80-87. doi:10.1016/j.applthermaleng.2013.01.051.

[29] M.R.W. Walmsley, T.G. Walmsley, L. Matthews, M.J. Atkins, J.R. Neale, P.J.J. Kamp, Pinch analysis techniques for carbon emissions reduction in the New Zealand industrial process heat sector, Chemical Engineering Transactions. 45 (2015) 1087-1092. doi:10.3303/CET1545182.

[30] L. Sun, S. Doyle, R. Smith, Cogeneration improvement based on steam cascade analysis, Chemical Engineering Transactions. 35 (2013) 13-18. doi:10.3303/CET1335002.

[31] M.H.K. Manesh, S.K. Abadi, H. Ghalami, M. Amidpour, M.H. Hamedi, A New Cogeneration Targeting Procedure for Total Site, Chemical Engineering Transactions. 29 (2012) 1561-1566.

[32] M. Yang, X. Feng, G. Liu, Heat Exchanger Network Design Considering the Heat Pump Performance, Chemical Engineering Transactions. 39 (2014) 1099-1104.

[33] T.G. Walmsley, M.J. Atkins, M.R.W. Walmsley, J.R. Neale, M. Philipp, R.H. Peesel, G. Schumm, Total Site utility systems optimisation for milk powder production, Chemical Engineering Transactions. 52 (2016) 235-240. doi:10.3303/CET1652040.

[34] D.J. Oldfield, M.W. Taylor, H. Singh, Effect of preheating and other process parameters on whey protein reactions during skim milk powder manufacture, International Dairy Journal. 15 (2005) 501-511. doi:10.1016/j.idairyj.2004.09.004. 
[35] A.J. Baldwin, H.R. Cooper, K.C. Palmer, Effect of preheat treatment and storage on the properties of whole milk powder. Changes in sensory properties, Netherlands Milk and Dairy Journal. 45 (1991) 97-116.

[36] A.R. Hinton, Thermophiles and fouling deposits in milk powder plants, PhD Thesis, Massey University, 2003. muir.massey.ac.nz/handle/10179/1861 (accessed July 3, 2012).

[37] T.G. Walmsley, M.R.W. Walmsley, M.J. Atkins, J.R. Neale, Fouling and pressure drop analysis of milk powder deposition on the front of parallel fins, Advanced Powder Technology. 24 (2013) 780-785. doi:10.1016/j.apt.2013.04.004.

[38] J.J. Klemeš, P.S. Varbanov, A.S.R.W. Wan, Z.A. Manan, Process Integration and Intensification, Saving Energy, Water and Resources, De Gruyter, Berlin, Boston, 2014.

[39] M.R.W. Walmsley, T.G. Walmsley, M.J. Atkins, P.J.J. Kamp, J.R. Neale, Minimising carbon emissions and energy expended for electricity generation in New Zealand through to 2050, Applied Energy. 135 (2014) 656-665. doi:10.1016/j.apenergy.2014.04.048.

[40] Ministry for the Environment, Emission factors and methods 2007, Ministry for the Environment. (2007). mfe.govt.nz/publications/climate/guidance-greenhouse-gasreporting-2008-09/html/page3.html (accessed March 26, 2015).

[41] MAF Quality Management, Physical Properties of Dairy Products, 3rd ed., MAF Quality Management, Hamilton, New Zealand, 1996.

[42] J. Sargolzaei, M.R. Pirzadi Jahromi, E. Saljoughi, Triple-Choking Model for Ejector, J. Thermal Sci. Eng. Appl. 2 (2010) 021009-021009. doi:10.1115/1.4002752.

[43] Membrane System Specialists, Reverse Osmosis, MSS. (2016). www.mssincorporated.com/reverseosmosis.htm (accessed December 1, 2016).

[44] J.M. Medina-Flores, M. Picón-Núñez, Modelling the power production of single and multiple extraction steam turbines, Chemical Engineering Science. 65 (2010) 28112820. doi:10.1016/j.ces.2010.01.016. 


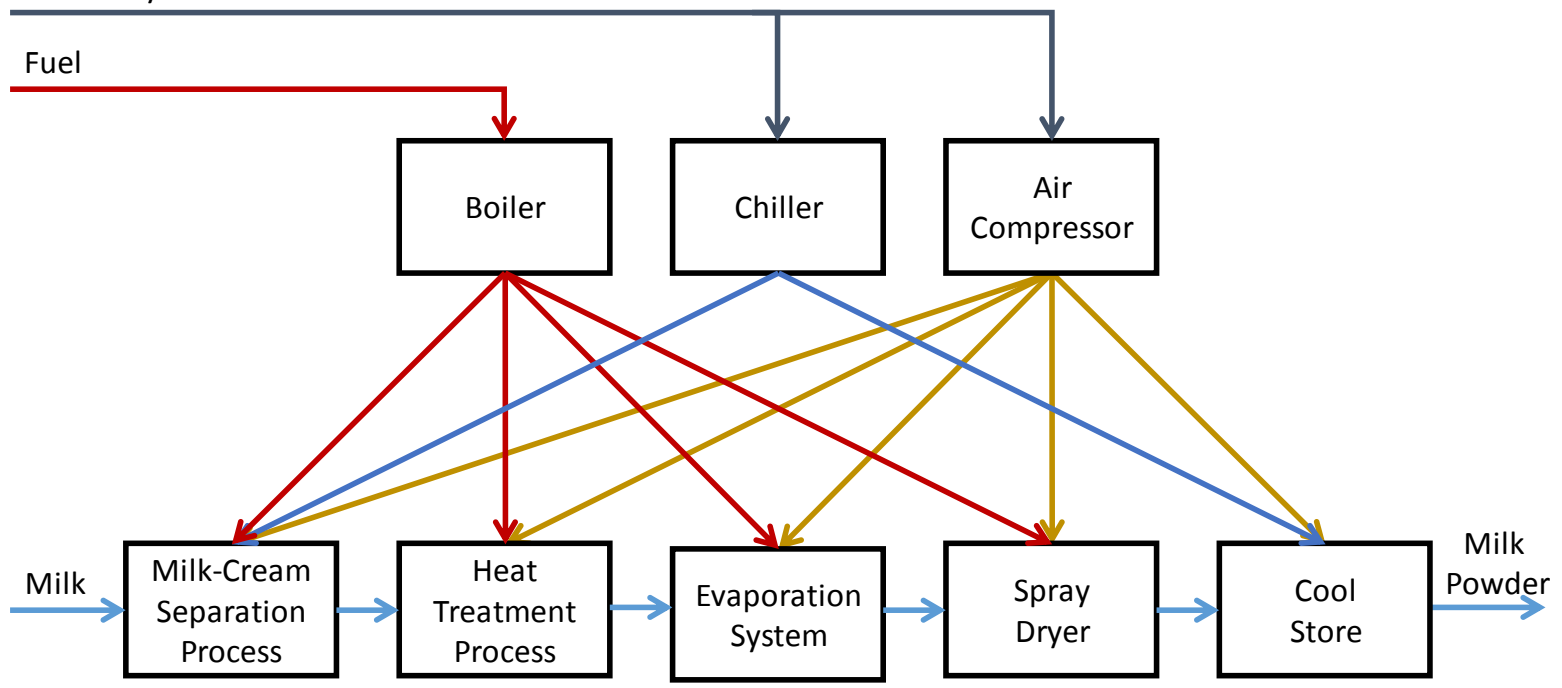

Figure 1: Modern stand-alone milk powder factory overview. 


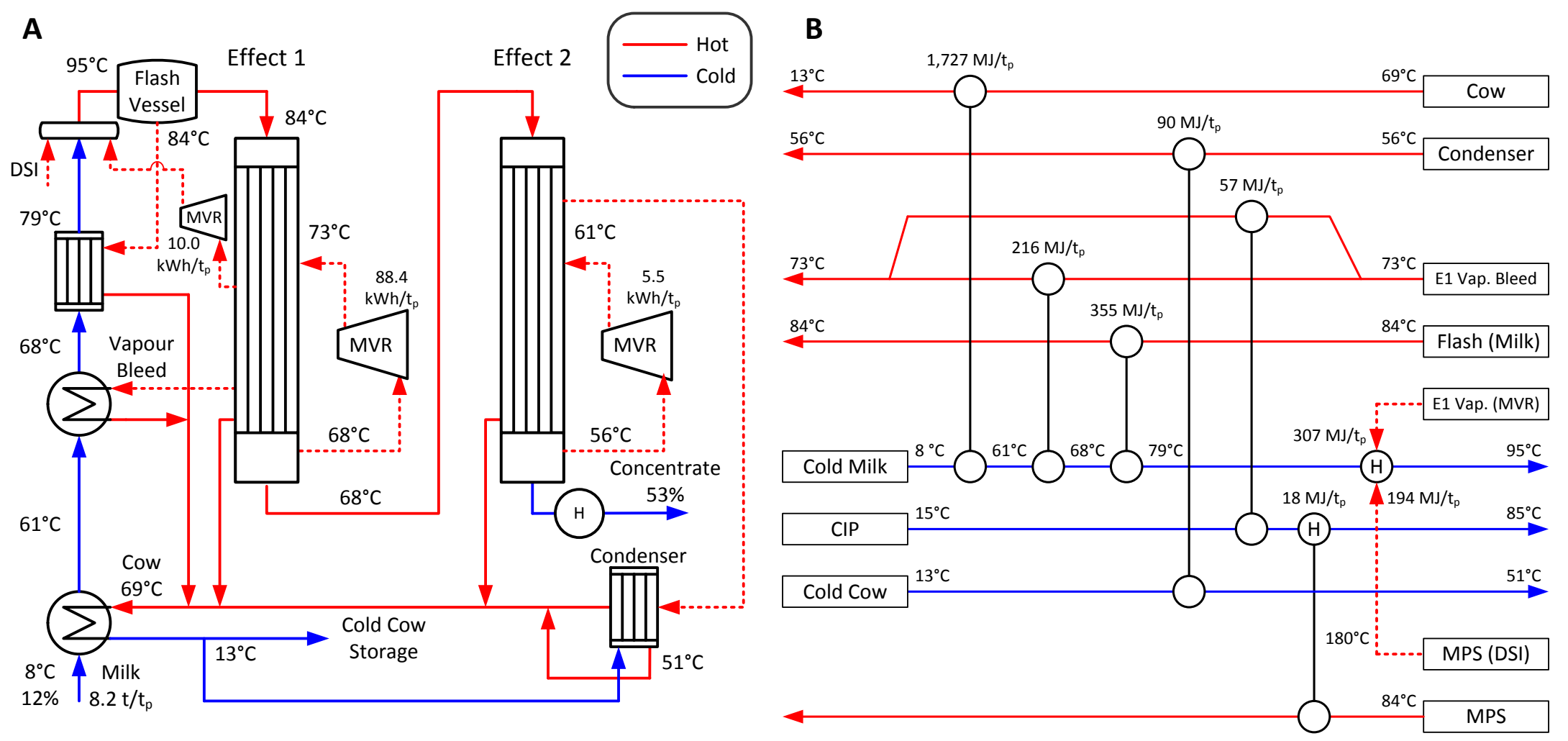

Figure 2: Ultra-low energy milk evaporation system. Design illustrated using a process flow diagram (A) and grid diagram (B). Process design from Walmsley et al. [5]. 


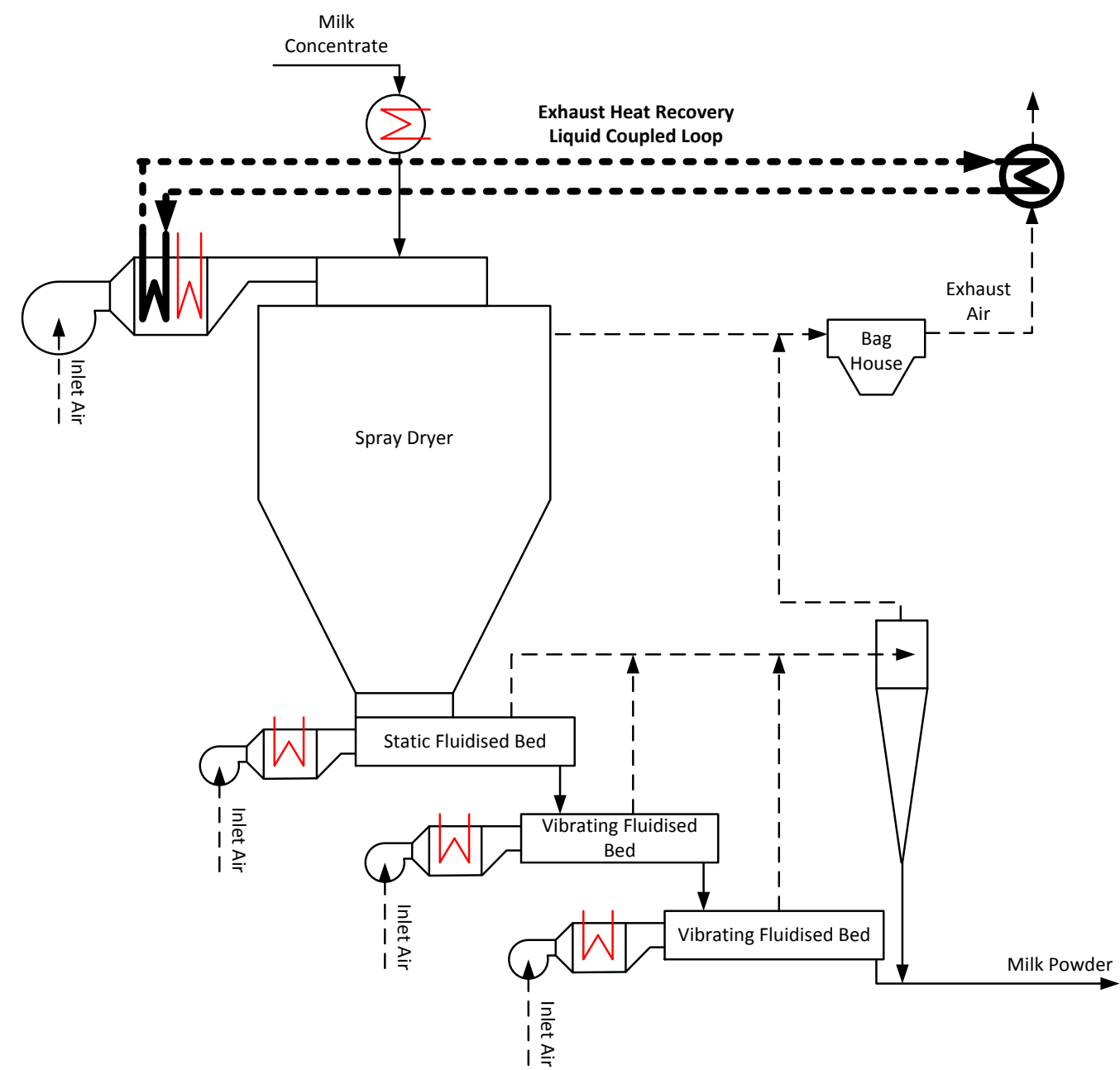

Figure 3: Milk spray dryer showing indirect exhaust heat recovery using a liquid coupled loop heat exchanger system. 


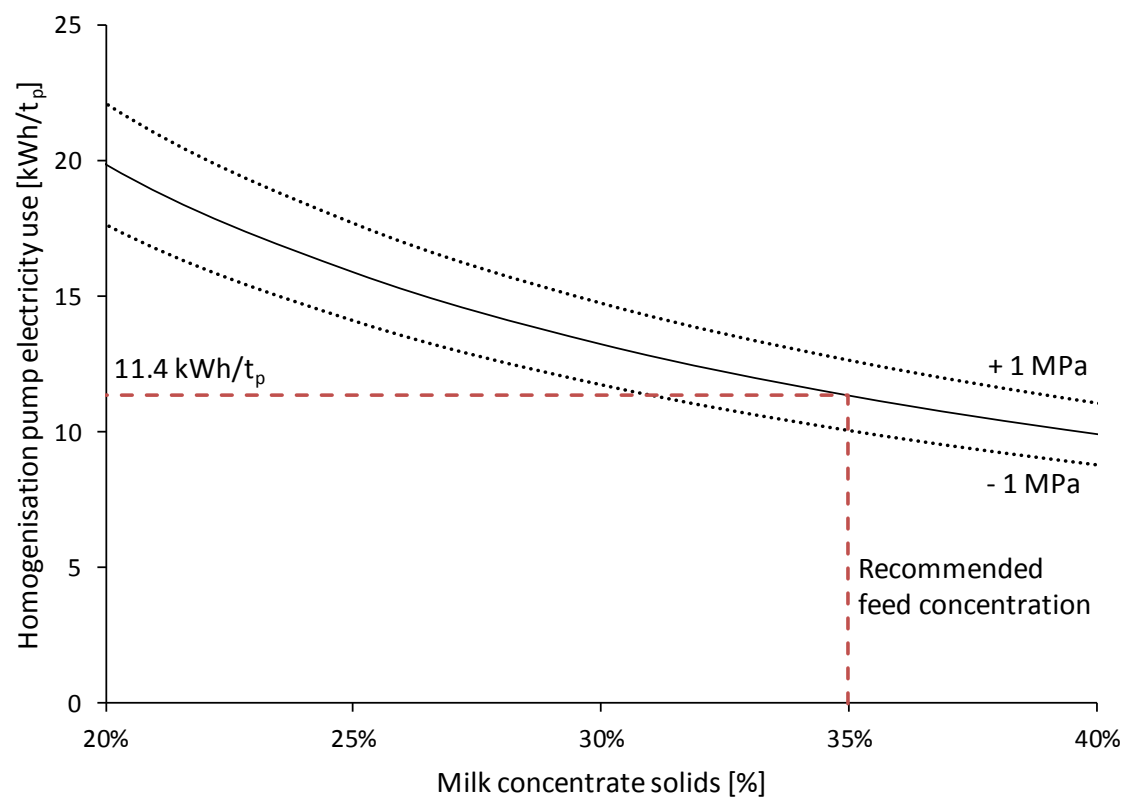

Figure 4: Milk concentrate two-stage homogenisation process electricity use.

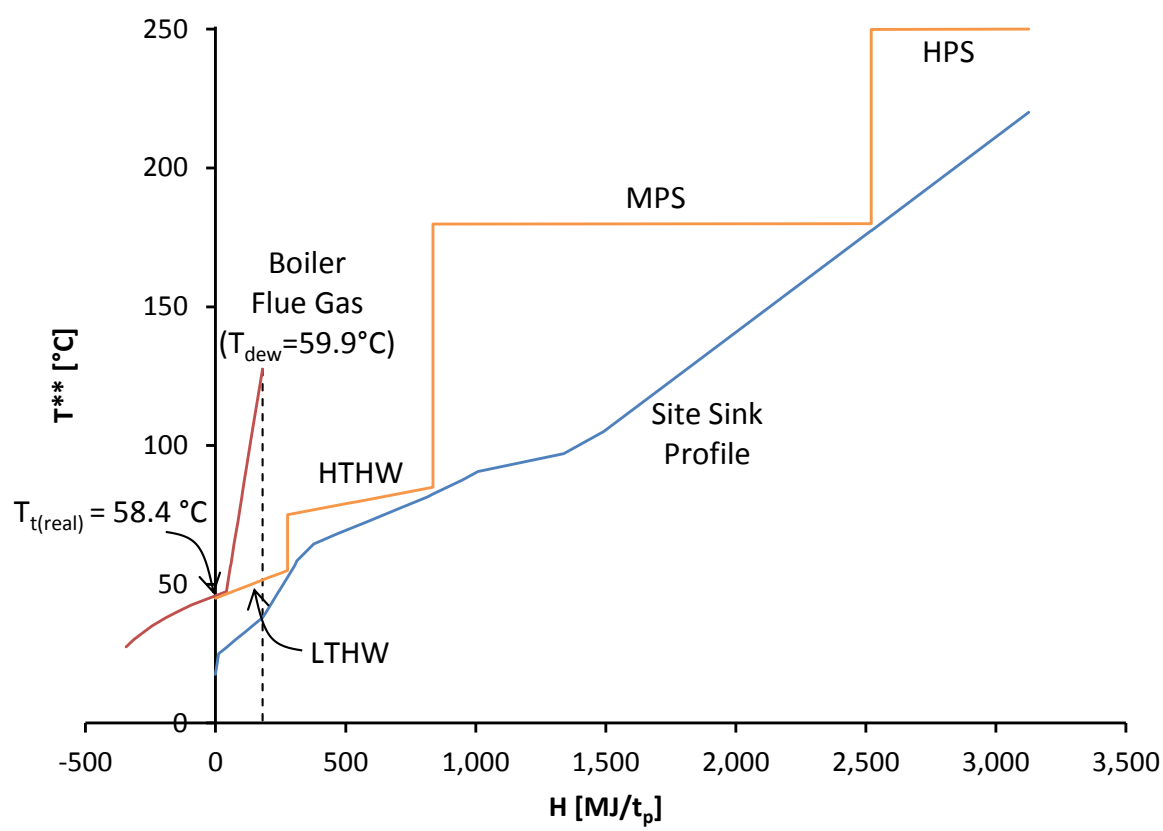

Figure 5: Target for the minimum boiler flue gas temperature by pinching the flue gas profile with the site hot water utility system. 


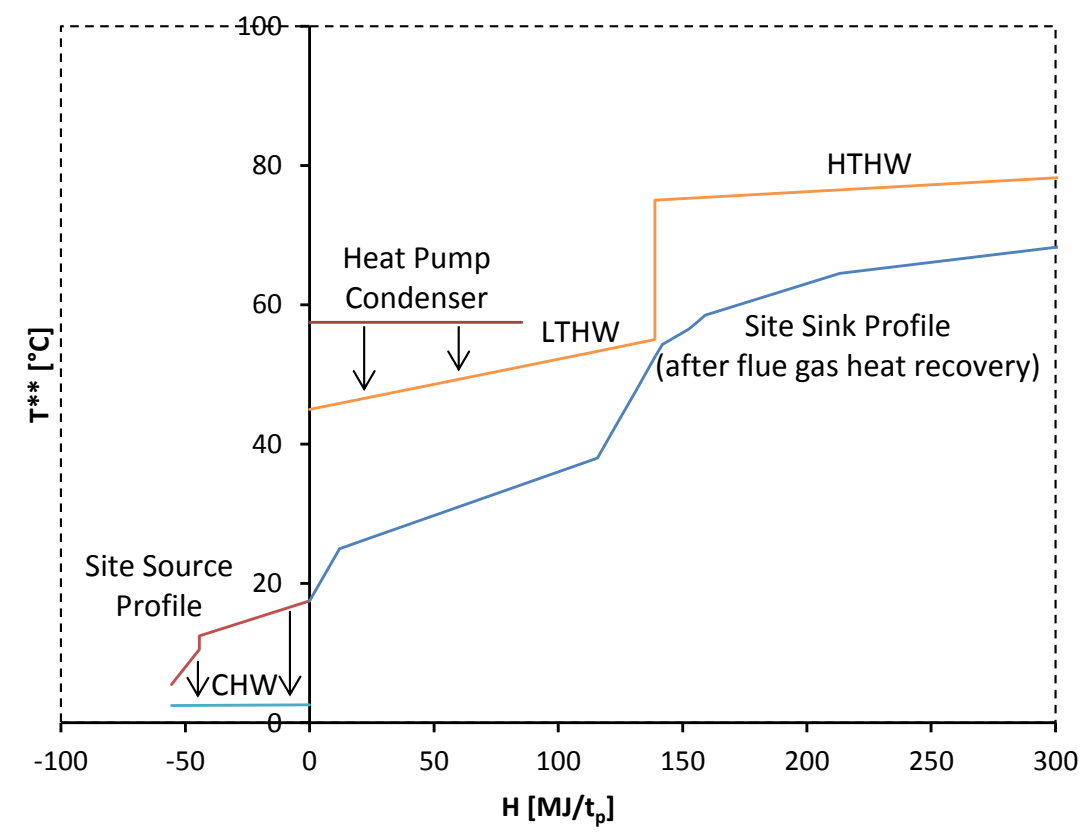

Figure 6: Combined chiller (through chilled water) and heat pump condenser integration with Total Site Profiles. Note: axes are zoomed; only a portion of the Total Site Profiles is shown.

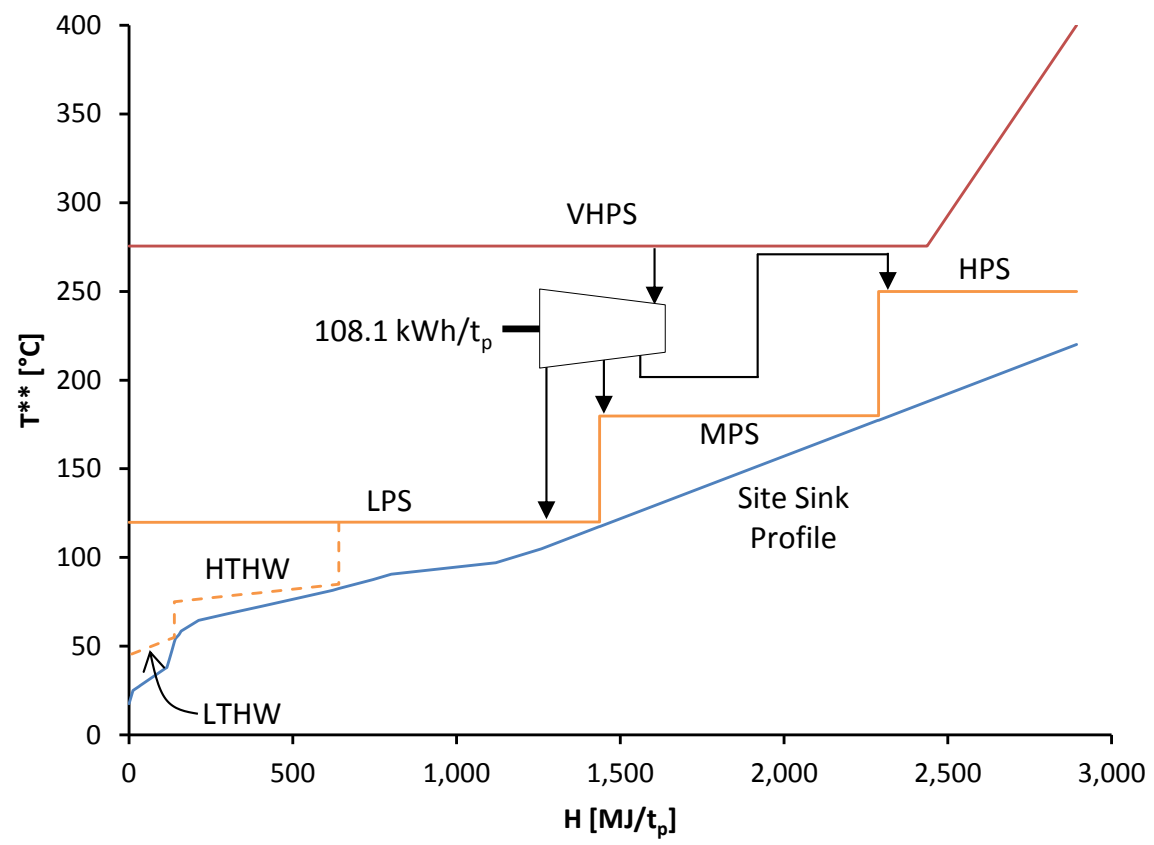

Figure 7: Combined heat and power system using Total Site Profiles. 


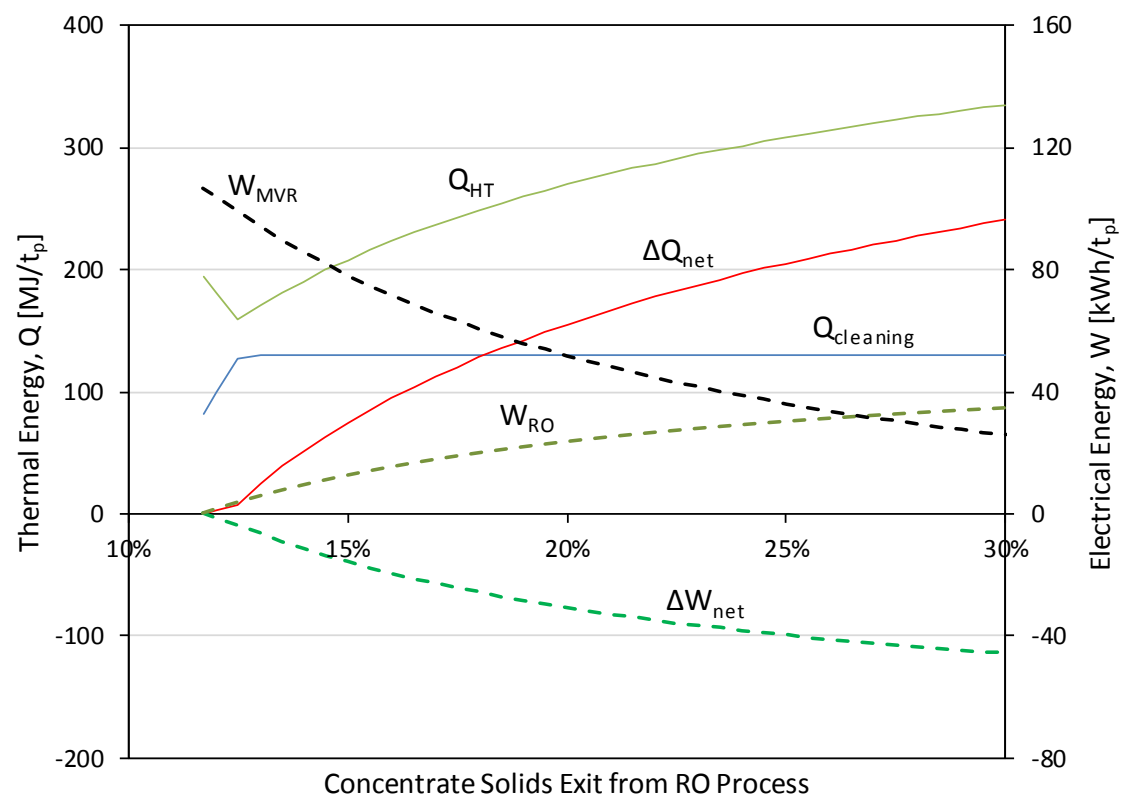

Figure 8: Effect of RO concentrate solids for Design 2.1 on thermal and electrical energy use for overall use (net), heat treatment process (HT), cleaning, MVR evaporator and RO process.

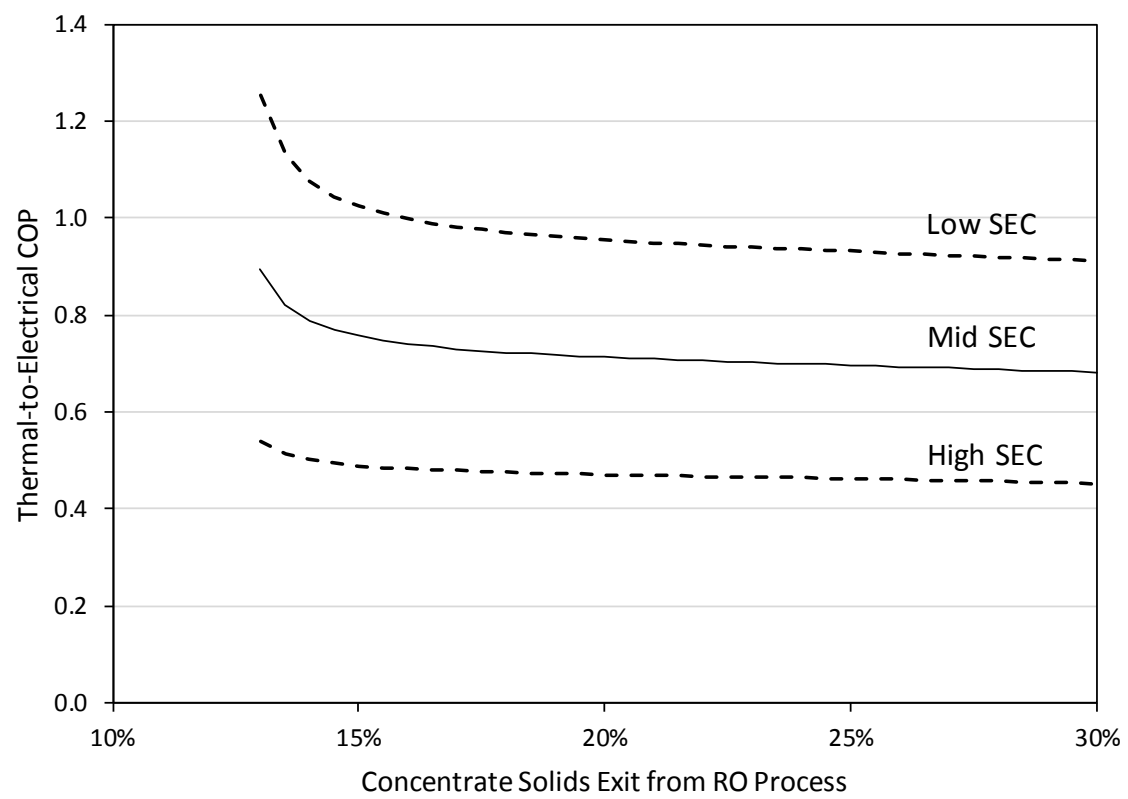

Figure 9: Effect of RO concentrate solids on equivalent thermal-to-electrical COP given a low, mid, and high SEC for RO. 


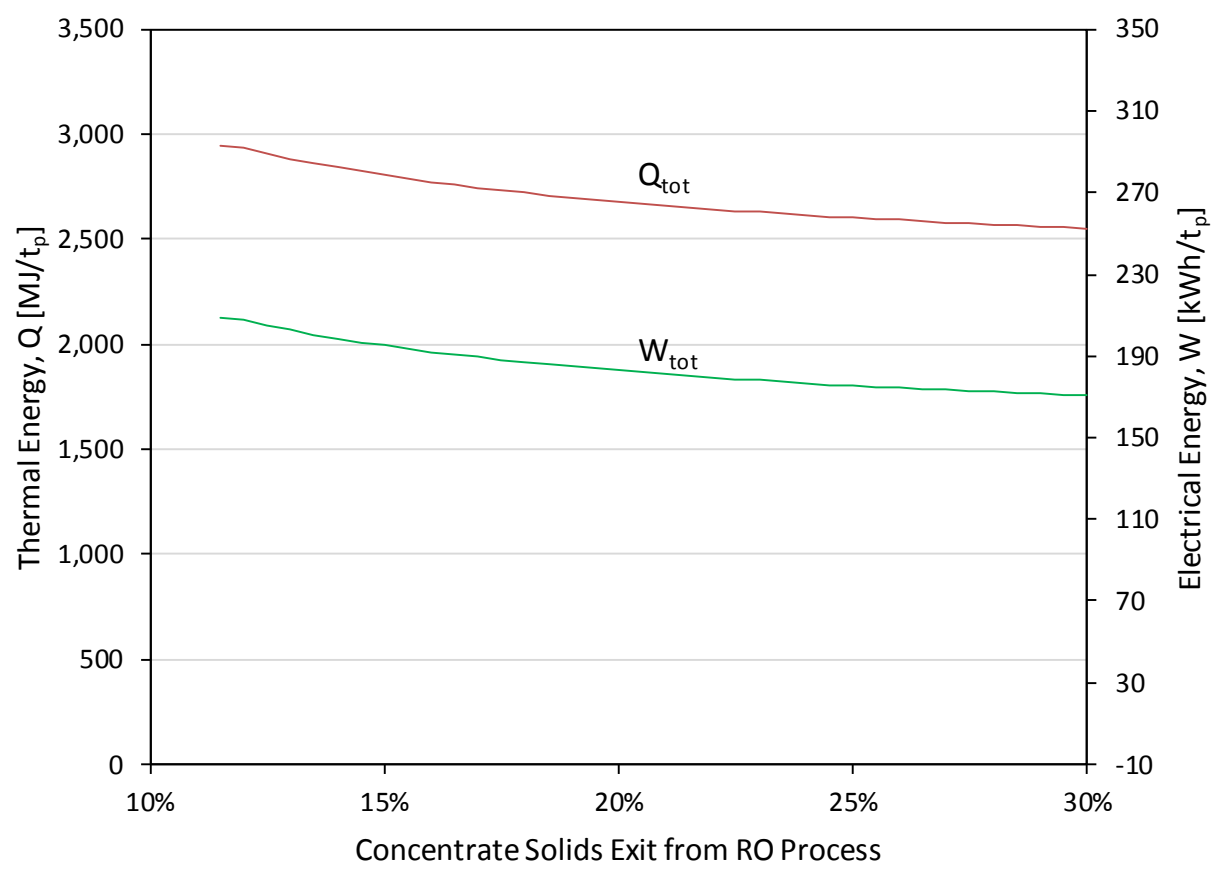

Figure 10: Effect of RO concentrate solids for Design 3.0 on thermal and electrical energy use for overall use (net), heat treatment process (HT), cleaning, MVR evaporator and RO process. 

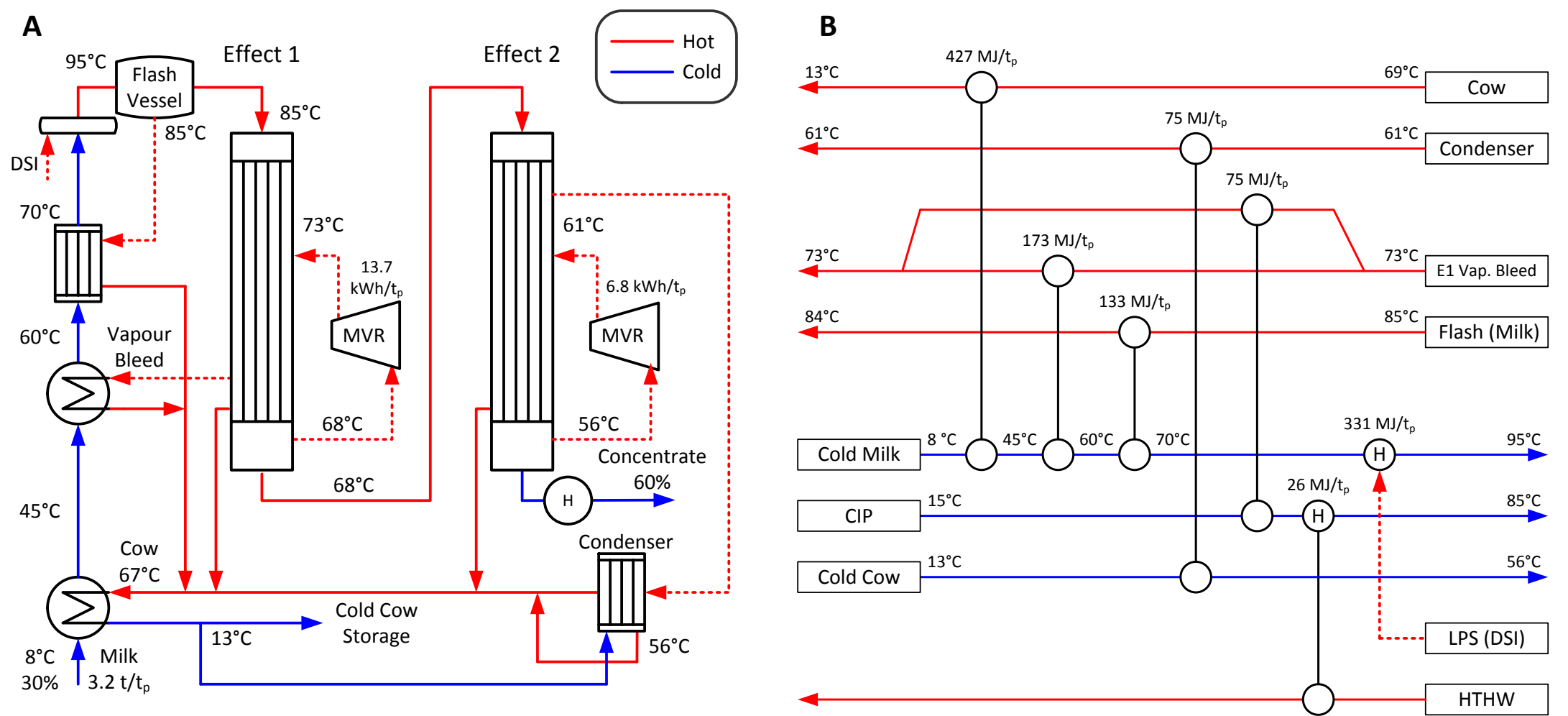

Figure 11: Milk evaporation system design for an ultra-low energy milk powder plant with integrate RO pre-concentration and high solids spray drying. Design illustrated using a process flow diagram (A) and grid diagram (B). 


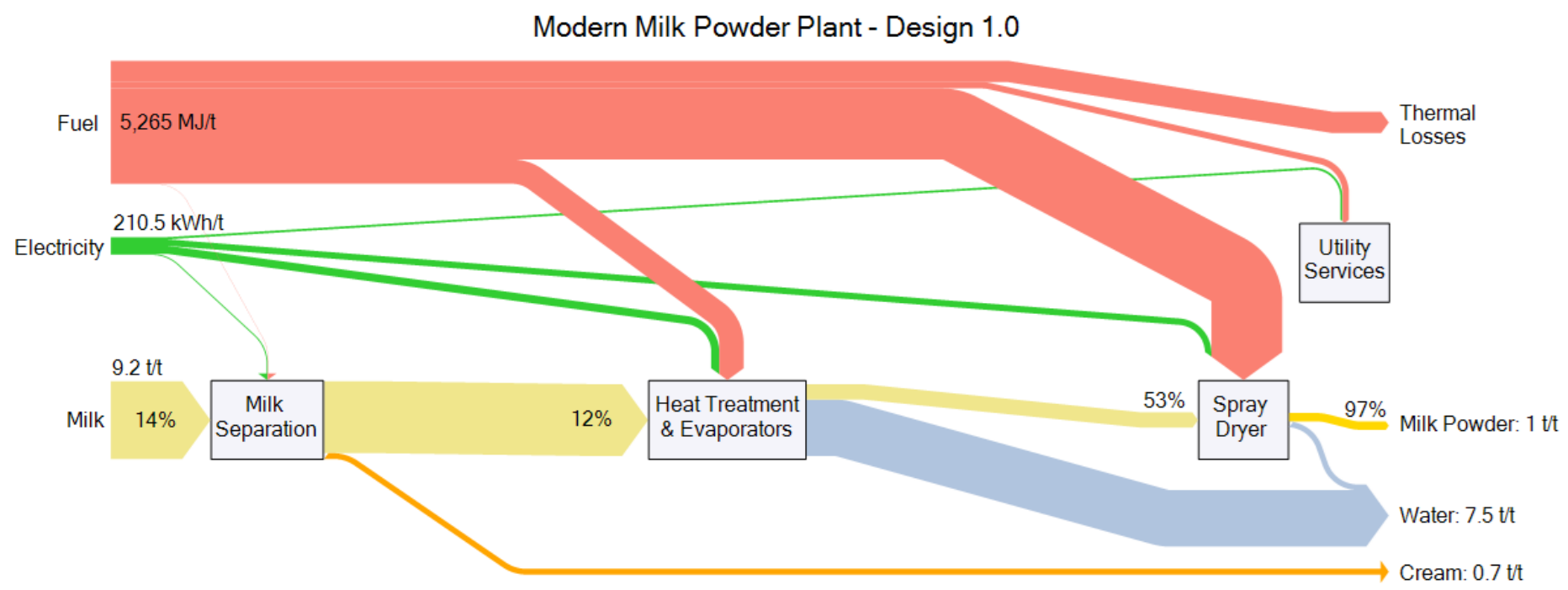

Ultra-Low Energy Milk Powder Plant - Design 3.0

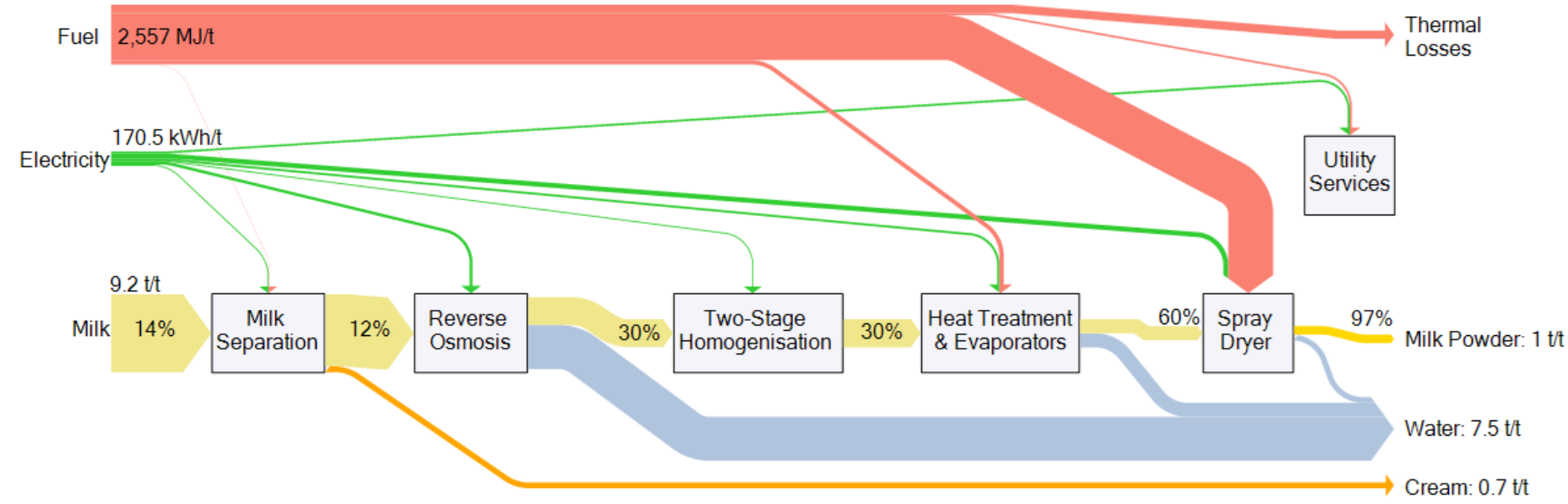

Figure 12: Sankey diagrams for a modern milk powder plant and an ultra-low energy milk powder plant, comparing energy, water removal, and product flows. 
Table 1: Process and utility design changes. *Utility systems changes investigated using the basis of Design 2.0 and then incorporated into the final design, Design 3.0.

\begin{tabular}{lccccc}
\hline Process Design & Design 2.0 & Design 2.1 & Design 2.2 & Design 2.3 & Design 3.0 \\
\hline $\begin{array}{l}\text { Ultra-low energy heat } \\
\text { treatment \& evaporator }\end{array}$ & $\checkmark$ & $\checkmark$ & $\checkmark$ & $\checkmark$ & $\checkmark$ \\
$\begin{array}{l}\text { system } \\
\text { Spray dryer exhaust heat } \\
\text { recovery }\end{array}$ & $\checkmark$ & $\checkmark$ & $\checkmark$ & $\checkmark$ & $\checkmark$ \\
RO Pre-concentration & & $\checkmark$ & $\checkmark$ & $\checkmark$ & $\checkmark$ \\
$\begin{array}{l}\text { High solids spray drying } \\
\text { Boiler condensing } \\
\text { economiser } \\
\text { Chiller waste heat } \\
\text { recovery } \\
\text { HVAC air recycle }\end{array}$ & $*$ & & & $\checkmark$ \\
Combined Heat and & $*$ & & & $\checkmark$ \\
Power
\end{tabular}

Table 2: Reverse osmosis specific energy consumptions, per tonne of water removed and per tonne of powder product, for concentrating milk from $12 \%$ to $30 \%$ solids.

\begin{tabular}{ccc}
\hline Case & SEC $\left[\mathrm{kWh} / \mathrm{t}_{\mathrm{w}}\right]$ & $\mathrm{SEC}\left[\mathrm{kWh} / \mathrm{t}_{\mathrm{p}}\right]$ \\
\hline Low & 3.9 & 19.6 \\
Mid & 7.0 & 35.0 \\
High & 10.0 & 50.3 \\
\hline
\end{tabular}


Table 3: Break-down of specific thermal and electrical uses in modern milk powder plant design (1.0), future design (2.0), which includes sub-designs with RO preconcentration (2.1), high solids drying (2.2), and combination of these two process changes (2.3), and the novel ultra-low energy process and utility design (3.0).

\begin{tabular}{|c|c|c|c|c|c|c|c|c|c|c|c|c|c|}
\hline \multirow{2}{*}{ Zone } & \multirow{2}{*}{$\begin{array}{l}\text { Major } \\
\text { Equipment }\end{array}$} & \multicolumn{6}{|c|}{$\begin{array}{c}\text { Thermal Energy } \\
\text { Use }\left[\mathrm{MJ} / \mathrm{t}_{\mathrm{p}}\right]\end{array}$} & \multicolumn{6}{|c|}{$\begin{array}{c}\text { Electrical Use } \\
{\left[\mathrm{kWh} / \mathrm{t}_{\mathrm{p}}\right]}\end{array}$} \\
\hline & & $\begin{array}{l}\text { Design } \\
1.0\end{array}$ & $\begin{array}{l}\text { Design } \\
2.0\end{array}$ & $\begin{array}{c}\text { Design } \\
2.1\end{array}$ & $\begin{array}{l}\text { Design } \\
2.2\end{array}$ & $\begin{array}{c}\text { Design } \\
2.3\end{array}$ & $\begin{array}{c}\text { Design } \\
3.0\end{array}$ & $\begin{array}{l}\text { Design } \\
1.0\end{array}$ & $\begin{array}{c}\text { Design } \\
2.0\end{array}$ & $\begin{array}{l}\text { Design } \\
2.1\end{array}$ & $\begin{array}{l}\text { Design } \\
2.2\end{array}$ & $\begin{array}{c}\text { Design } \\
2.3\end{array}$ & $\begin{array}{l}\text { Design } \\
3.0\end{array}$ \\
\hline Milk Separation & $\begin{array}{l}\text { Cream pasteurisation } \\
\text { Process pumps }\end{array}$ & $\begin{array}{c}11 \\
-\end{array}$ & $\begin{array}{c}11 \\
-\end{array}$ & $\begin{array}{c}11 \\
-\end{array}$ & $\begin{array}{c}11 \\
-\end{array}$ & $\begin{array}{c}11 \\
-\end{array}$ & $\begin{array}{c}11 \\
-\end{array}$ & $\begin{array}{c}- \\
13.1\end{array}$ & $\begin{array}{c}- \\
13.1\end{array}$ & $\begin{array}{c}- \\
13.1\end{array}$ & $\begin{array}{c}- \\
13.1\end{array}$ & $\begin{array}{c}- \\
13.1\end{array}$ & $\begin{array}{c}- \\
13.1\end{array}$ \\
\hline $\begin{array}{l}\text { Reverse } \\
\text { Osmosis }\end{array}$ & Process pumps & - & - & - & - & - & - & - & - & 35.0 & - & 35.0 & 35.0 \\
\hline \multirow{4}{*}{$\begin{array}{l}\text { Heat Treatment } \\
\text { \& Evaporators }\end{array}$} & Heat treatment & 736 & 194 & 335 & 144 & 184 & 184 & - & 10.0 & - & 11.5 & - & - \\
\hline & MVR and TVR units & 305 & - & - & - & - & - & 92.7 & 93.9 & 20.7 & 97.1 & 23.9 & 23.9 \\
\hline & Process pumps & - & - & - & - & - & - & 2.6 & 2.6 & 2.6 & 2.6 & 2.6 & 2.6 \\
\hline & Two-stage homogeniser & - & - & - & - & - & - & - & - & - & 11.4 & 13.3 & 13.3 \\
\hline \multirow{5}{*}{ Spray Dryer } & Air heaters & 2,877 & 2,610 & 2,610 & 1,962 & 1,962 & 1,795 & - & - & - & - & - & - \\
\hline & Feed heater & 148 & 131 & 131 & 111 & 111 & 111 & - & - & - & - & - & - \\
\hline & Homogeniser feed pump & - & - & - & - & - & - & 7.8 & 7.8 & 7.8 & 6.9 & 6.9 & 6.9 \\
\hline & Process fans & - & - & - & - & - & - & 46.4 & 46.4 & 46.4 & 36.6 & 36.6 & 29.1 \\
\hline & Product handling & 10 & 10 & 10 & 10 & 10 & 10 & 22.1 & 22.1 & 22.1 & 22.1 & 22.1 & 22.1 \\
\hline \multirow{6}{*}{ Utility Services } & Cleaning and washing & 191 & 81 & 130 & 85 & 78 & 78 & - & - & - & - & - & - \\
\hline & HVAC & 83 & 83 & 83 & 83 & 83 & 8 & 7.3 & 7.3 & 7.3 & 7.3 & 7.3 & 7.3 \\
\hline & Chiller unit & - & - & - & - & - & - & 6.7 & 6.7 & 6.7 & 6.7 & 6.7 & 8.0 \\
\hline & Compressed air unit & - & - & - & - & - & - & 6.8 & 6.8 & 6.8 & 6.8 & 6.8 & 6.8 \\
\hline & Boiler pump and fan & - & - & - & - & - & - & 4.9 & 3.4 & 3.6 & 2.6 & 2.7 & 2.4 \\
\hline & Thermal losses & 903 & 573 & 624 & 451 & 462 & 357 & - & - & - & - & - & - \\
\hline \multicolumn{2}{|c|}{ Total Energy Consumption } & 5,265 & 3,694 & 3,934 & 2,856 & 2,900 & 2,554 & 210.5 & 220.2 & 172.2 & 224.7 & 177.0 & 170.5 \\
\hline \multicolumn{2}{|c|}{ Energy Reduction from Design 1.0} & - & $\begin{array}{c}1,571 \\
(29.8 \%)\end{array}$ & $\begin{array}{c}1,330 \\
(25.3 \%)\end{array}$ & $\begin{array}{c}2,409 \\
(45.7 \%)\end{array}$ & $\begin{array}{c}2,365 \\
(44.9 \%)\end{array}$ & $\begin{array}{c}2,711 \\
(51.5 \%)\end{array}$ & - & $\begin{array}{c}-9.7 \\
(-4.6 \%)\end{array}$ & $\begin{array}{c}38.2 \\
(18.2 \%)\end{array}$ & $\begin{array}{c}-14.3 \\
(-6.8 \%)\end{array}$ & $\begin{array}{c}33.5 \\
(15.9 \%)\end{array}$ & $\begin{array}{c}40.0 \\
(19.0 \%)\end{array}$ \\
\hline \multicolumn{2}{|c|}{ Energy Reduction from Design 2.0} & - & - & $\begin{array}{c}-241 \\
(-6.5 \%)\end{array}$ & $\begin{array}{c}837 \\
(22.7 \%)\end{array}$ & $\begin{array}{c}794 \\
(21.5 \%)\end{array}$ & $\begin{array}{c}1,139 \\
(30.8 \%)\end{array}$ & - & _ & $\begin{array}{c}48.0 \\
(21.8 \%)\end{array}$ & $\begin{array}{c}-4.5 \\
(-2.1 \%)\end{array}$ & $\begin{array}{c}43.3 \\
(19.6 \%)\end{array}$ & $\begin{array}{c}49.7 \\
(22.6 \%)\end{array}$ \\
\hline
\end{tabular}


Table 4: Carbon equivalent emissions arising from thermal and electrical energy demand for various milk powder plant designs.

\begin{tabular}{lcccc}
\hline Process Design & $\begin{array}{c}\text { Emissions from } \\
\text { Thermal Energy Use } \\
{\left[\mathrm{kgC2-e}_{\mathrm{co}} / \mathrm{t}_{\mathrm{p}}\right]}\end{array}$ & $\begin{array}{c}\text { Emissions from } \\
\text { Electricity Use } \\
{\left[\mathrm{kg}_{\mathrm{CO} 2 \mathrm{e}} / \mathrm{t}_{\mathrm{p}}\right]}\end{array}$ & $\begin{array}{c}\text { Total Emissions } \\
{\left[\mathrm{kg}_{\text {cO2-e } \mathrm{e}} / \mathrm{t}_{\mathrm{p}}\right]}\end{array}$ & $\begin{array}{c}\text { Percent Emissions } \\
\text { Reduction }\end{array}$ \\
\hline Design 1.0 & 280.6 & 27.2 & 307.8 & - \\
Design 2.0 & 196.9 & 28.5 & 225.3 & $26.8 \%$ \\
Design 2.1 & 209.7 & 22.3 & 232.0 & $24.6 \%$ \\
Design 2.2 & 152.2 & 29.0 & 181.3 & $41.1 \%$ \\
Design 2.3 & 154.6 & 22.9 & 177.4 & $42.4 \%$ \\
Design 3.0 & 136.1 & 22.0 & 158.2 & $48.6 \%$ \\
\hline
\end{tabular}




\section{Appendix 1: Stream Data for Total Site Profiles}

Table 5: Stream data for the Total Site Profiles in Design 1.0.

\begin{tabular}{|c|c|c|c|c|c|}
\hline \multirow[t]{2}{*}{ Process } & \multirow[t]{2}{*}{ Stream Name } & $\mathrm{T}_{\mathrm{s}}$ & $\mathrm{T}_{\mathrm{t}}$ & $\mathrm{CP}$ & $\mathrm{Q}$ \\
\hline & & ${ }^{\circ} \mathrm{C}$ & ${ }^{\circ} \mathrm{C}$ & $\mathrm{MJ} /\left(\mathrm{t}_{\mathrm{p}}{ }^{\circ} \mathrm{C}\right)$ & $\mathrm{MJ} / \mathrm{t}_{\mathrm{p}}$ \\
\hline \multirow{2}{*}{ Milk Treatment } & Cream C & 80 & 85 & 2.2 & 11 \\
\hline & Cream H & 13 & 8 & 2.2 & 11 \\
\hline \multirow{2}{*}{$\begin{array}{l}\text { Heat Treatment and } \\
\text { Evaporator }\end{array}$} & Cold Milk & 74 & 95 & 32.8 & 676 \\
\hline & CIP & 15 & 85 & 1.1 & 77 \\
\hline \multirow{4}{*}{ Spray Dryer } & Milk concentrate & 53 & 79 & 5.7 & 148 \\
\hline & Dryer Inlet Air & 28 & 210 & 14.2 & 2581 \\
\hline & HVAC & 15 & 28 & 6.4 & 83 \\
\hline & FB Inlet Air & 28 & 95 & 4.4 & 296 \\
\hline \multirow{3}{*}{ Other } & Tanker wash and direct use & 15 & 54 & 1.3 & 53 \\
\hline & CIP and reconstitution & 15 & 54 & 0.3 & 10 \\
\hline & Cool stores & 20 & 15 & 8.9 & 44 \\
\hline
\end{tabular}

Table 6: Stream data for the Total Site Profiles in Design 2.0 and the basis for targeting increased utility integration.

\begin{tabular}{llcccc}
\hline \multirow{2}{*}{ Process } & \multicolumn{1}{c}{ Stream Name } & $\mathrm{T}_{\mathrm{s}}$ & $\mathrm{T}_{\mathrm{t}}$ & $\mathrm{CP}$ & $\mathrm{Q}$ \\
& & ${ }^{\circ} \mathrm{C}$ & ${ }^{\circ} \mathrm{C}$ & $\mathrm{MJ} /\left(\mathrm{t}_{\mathrm{p}}{ }^{\circ} \mathrm{C}\right)$ & $\mathrm{MJ} / \mathrm{t}_{\mathrm{p}}$ \\
\hline \multirow{2}{*}{ Milk Treatment } & Cream C & 80 & 85 & 2.2 & 11 \\
& Cream H & 13 & 8 & 2.2 & 11 \\
\hline \multirow{2}{*}{ Heat Treatment and } & Cold Milk & 89 & 95 & 32.7 & 194 \\
Evaporator & CIP & 59 & 85 & 1.1 & 29 \\
\hline \multirow{4}{*}{ Spray Dryer } & Milk concentrate & 56 & 79 & 5.7 & 131 \\
& Dryer Inlet Air & 54 & 210 & 14.2 & 2210 \\
& HVAC & 15 & 28 & 6.4 & 83 \\
& FB Inlet Air & 15 & 95 & 5.0 & 400 \\
\hline \multirow{3}{*}{ Other } & Tanker wash and direct use & 15 & 54 & 1.3 & 53 \\
& CIP and reconstitution & 15 & 54 & 0.3 & 10 \\
& Cool stores & 20 & 15 & 8.9 & 44 \\
\hline
\end{tabular}


Table 7: Stream data for the Total Site Profiles in Design 3.0.

\begin{tabular}{llcccc}
\hline \multirow{2}{*}{ Process } & \multicolumn{1}{c}{ Stream Name } & $\begin{array}{c}\mathrm{T}_{\mathrm{s}} \\
{ }^{\circ} \mathrm{C}\end{array}$ & $\begin{array}{c}\mathrm{T}_{\mathrm{t}} \\
{ }^{\circ} \mathrm{C}\end{array}$ & $\begin{array}{c}\mathrm{CP} \\
\mathrm{MJ} /\left(\mathrm{t}_{\mathrm{p}}{ }^{\circ} \mathrm{C}\right)\end{array}$ & $\begin{array}{c}\mathrm{Q} \\
\mathrm{MJ} / \mathrm{t}_{\mathrm{p}}\end{array}$ \\
\hline \multirow{2}{*}{ Milk Treatment } & Cream C & 80 & 85 & 2.2 & 11 \\
& Cream H & 13 & 8 & 2.2 & 11 \\
\hline \multirow{2}{*}{ Heat Treatment and } & Cold Milk & 79 & 95 & 32.7 & 519 \\
& ClP & 66 & 85 & 1.1 & 21 \\
\hline \multirow{3}{*}{ Spray Dryer } & Milk concentrate & 56 & 79 & 4.8 & 111 \\
& Dryer Inlet Air & 57 & 210 & 10.5 & 1610 \\
& HVAC & 15 & 28 & 16.9 & 219 \\
& FB Inlet Air & 41 & 95 & 3.4 & 185 \\
\hline \multirow{3}{*}{ Other } & Tanker wash and direct use & 15 & 54 & 1.3 & 53 \\
& CIP and reconstitution & 15 & 54 & 0.3 & 10 \\
& Cool stores & 20 & 15 & 11.1 & 55 \\
\hline
\end{tabular}


Elsevier Editorial System(tm) for Energy Manuscript Draft

Title: Process and Utility Systems Integration and Optimisation for Ultra-Low Energy Milk Powder Production

Article Type: SI: PRES 2016 ENERGY

Keywords: Process Integration; Milk Powder; Total Site; Process Modelling

Corresponding Author: Dr. Timothy Gordon Walmsley, Ph.D.

Corresponding Author's Institution: Brno University of Technology

First Author: Timothy G Walmsley, PhD

Order of Authors: Timothy G Walmsley, PhD; Martin J Atkins, PhD; Michael RW Walmsley, PhD; Matthias Philipp, PhD; Ron-Hendrik Peesel

Abstract: This study applies a Total site Heat Integration approach in conjunction with a detailed process and utility model, to develop an innovative ultra-low energy milk powder plant design. The basis for the analysis is a state-of-the-art modern milk powder plant that requires $5,265 \mathrm{MJ} / \mathrm{tp}$ of fuel and $210.5 \mathrm{kWh} / \mathrm{tp}$ (58.5 MJe/tp) of electricity. The model of the modern milk powder plant was validated against industrial data and changes to process and/or utility systems are targeted and implemented into the model to understand the impacts on thermal and electrical demands and emissions. Results show that seven significant changes are beneficial: (1) pre-concentration of milk to $30 \%$ using reverse osmosis, (2) a two-stage intermediate concentrate (30 \%) homogenisation to enable high solids (60 \%) spray drying, (3) an ultralow energy Mechanical Vapour Recompression evaporator system, (4) spray dryer exhaust heat recovery, (5) condensing economiser for the boiler, (6) upgrade and integration of chiller condenser heat with hot water utility systems, and (7) recycling of air in the building ventilation system. These changes are estimated to reduce thermal energy use by 51.5 \%, electricity use by $19.0 \%$, and emissions by $48.6 \%$ compared to a modern milk powder plant. 